IZA DP No. 9106

Number of Siblings and Educational Choices of Immigrant Children: Evidence from First- and Second-Generation Immigrants

Dominique Meurs

Patrick A. Puhani

Friederike Von Haaren

June 2015 


\title{
Number of Siblings and Educational Choices of Immigrant Children: Evidence from First- and Second-Generation Immigrants
}

\author{
Dominique Meurs \\ EconomiX, Université Paris-Ouest et INED \\ Patrick A. Puhani \\ Leibniz Universität Hannover, \\ CreAM, SEW and IZA \\ Friederike Von Haaren \\ NIW Hannover and Leibniz Universität Hannover
}

Discussion Paper No. 9106

June 2015

IZA
P.O. Box 7240
53072 Bonn
Germany

Phone: +49-228-3894-0

Fax: +49-228-3894-180

E-mail: iza@iza.org

\begin{abstract}
Any opinions expressed here are those of the author(s) and not those of IZA. Research published in this series may include views on policy, but the institute itself takes no institutional policy positions. The IZA research network is committed to the IZA Guiding Principles of Research Integrity.

The Institute for the Study of Labor (IZA) in Bonn is a local and virtual international research center and a place of communication between science, politics and business. IZA is an independent nonprofit organization supported by Deutsche Post Foundation. The center is associated with the University of Bonn and offers a stimulating research environment through its international network, workshops and conferences, data service, project support, research visits and doctoral program. IZA engages in (i) original and internationally competitive research in all fields of labor economics, (ii) development of policy concepts, and (iii) dissemination of research results and concepts to the interested public.
\end{abstract}

IZA Discussion Papers often represent preliminary work and are circulated to encourage discussion. Citation of such a paper should account for its provisional character. A revised version may be available directly from the author. 


\section{ABSTRACT}

\section{Number of Siblings and Educational Choices of Immigrant Children: Evidence from First- and Second-Generation Immigrants ${ }^{\star}$}

We document the educational integration of immigrant children with a focus on the link between family size and educational decisions and distinguishing particularly between firstand second-generation immigrants and between source country groups. First, for immigrant adolescents, we show family-size adjusted convergence to almost native levels of higher education track attendance from the first to the second generation of immigrants. Second, we find that reduced fertility is associated with higher educational outcomes for immigrant children, possibly through a quantity-quality trade-off. Third, we show that between one third and the complete difference in family-size adjusted educational outcomes between immigrants from different source countries or immigrant generations can be explained by parental background. This latter holds true for various immigrant groups in both France and Germany, two major European economies with distinct immigration histories.

JEL Classification: J13, J15, J24

Keywords: migration, integration, quantity-quality trade-off, decomposition

Corresponding author:

Patrick A. Puhani

Leibniz Universität Hannover

Institut für Arbeitsökonomik

Königsworther Platz 1

D-30167 Hannover

Germany

E-mail: puhani@aoek.uni-hannover.de

\footnotetext{
* This project was partly supported by the Agence Nationale de la Recherche (ANR) and Deutsche Forschungsgemeinschaft (DFG) under the joint project "Integration of First and Second Generation Immigrants in France and Germany". We thank anonymous referees and seminar participants at the German Economic Association ("Verein für Socialpolitik") and at "Niedersächsischer Workshop in Applied Economics" for helpful comments. All remaining errors are our own.
} 


\section{$1 \quad$ Introduction}

Because of continuously high international migration flows, the integration of immigrants continues to be a prominent topic in both politics and academia. One widely accepted notion is that the better the integration of immigrants into the labor market, the higher should be their well-being and contribution to the host country's economy.

Since education is essential for future labor market success, we analyze determinants of educational decisions of adolescents. In particular, we focus on the link between family size and educational decisions (as posited in the quantity-quality trade-off theory), using data from France and Germany, two European countries with distinct immigration histories. First, we ask whether there is a relationship between the quantity of children and the quality of their education for natives and different groups of immigrants in France and Germany. Second, we ask whether immigrants from the first to the second generation move along the "quantity-quality trade-off" by reducing their fertility or whether the trade-off shifts upward between the first and the second generation in that educational outcomes improve for a given family size. Hence, a shifting tradeoff or moving along the quantity-quality trade-off by having fewer children with higher educational levels may be an important mechanism of integration across immigrant generations. We find that family size plays a significant role in explaining the educational gap between immigrant and native children and that over the generations, immigrants improve their educational outcomes, both through reducing their fertility and through other means, even for a given level of fertility.

This result is particularly important in the light of skeptical sentiments towards immigration that we currently observe and which is also reflected in recent election results in many European countries. Parts of the concerns are related to competition in the low-skill and 
low-wage sector. At the same time, a prominent but controversial observer in Germany has raised the issue of high fertility rates in connection with low educational levels (Sarrazin, 2010). Indeed, in most industrialized countries, a cross-sectional comparison of immigrants with natives will reveal that many immigrant groups have higher fertility and lower education (INSEE 2012, Statistisches Bundesamt 2012, Sweetman and van Ours 2014). Some people also fear the loss of national identity and other socio-cultural tensions. As Card, Dustmann and Preston (2012) show, opposition to immigration is based more on concerns about the ethnic composition of the neighborhood and one's co-workers than purely economic considerations.

However, this paper takes a more dynamic perspective by investigating whether over time (that is from the first to the second generation), immigrants reduce their fertility and increase their education to adjust to native levels. Although the literature has dealt with immigrants' fertility and educational success separately, the link between these two outcomes over generations of immigrants has hardly been analyzed so far. Kristen and Granato (2007) and Luthra (2010) present regressions with secondary schooling achievement as dependent variable where a linear term for the number of children enters as one of the regressors; in both cases, the coefficient of the linear term is statistically insignificant. ${ }^{1}$

Studies investigating fertility behavior of immigrants show that on the one hand immigrants' fertility is mostly higher compared to natives and similar to the fertility rate of the origin country, especially for first-generation immigrants (Toulement 2004; Stichnoth and Yeter 2013). On the other hand, differences in fertility behavior between natives and immigrants are smaller among second-generation immigrants, indicating a convergence to natives' fertility behavior (Milewski 2010 and Stichnoth and Yeter 2013).

\footnotetext{
${ }^{1}$ Our results below suggest that the relationship between school track attendance and number of siblings is nonlinear, with significant coefficients only for larger family sizes.
} 
The literature on the integration of immigrants across immigrant generations generally finds that the second generation of immigrants is more successful than the first, implying a "catching up" in relation to natives (Constant, Nottmeyer and Zimmermann 2009; Algan, Dustmann, Glitz and Manning 2010; Blau, Kahn, Liu and Papps 2013). This catch-up process is clearly demonstrated by Algan, Dustmann, Glitz and Manning (2010) for first- and secondgeneration immigrants in France, Germany and the United Kingdom. These authors find, however, that assimilation is larger in terms of education than in terms of labor market performance, an area in which-depending on the receiving and source countries in questionlarge gaps relative to natives may still prevail. Similarly, Gang and Zimmermann (2000) have previously illustrated that second generation immigrants lag behind natives in educational outcomes in Germany, and that this gap varies by immigrant citizenship. Riphahn (2003) argues that immigrants' changing country-of-origin composition explains that second-generation immigrants have been falling behind natives' educational outcomes over time. The studies by Kristen and Granato (2007), Luthra (2010), and Gresch and Kristen (2011) confirm the educational gap between second-generation immigrants and German natives but shows that it can be explained by parental background, such as parental education, income, and occupation. Indeed, all these three studies report that, once these parental background characteristics are controlled for, second-generation immigrants to Germany even outperform natives. Georgiadis and Manning (2011) show that Muslim communities in the UK differ from both natives and other immigrant groups but that there is significant convergence in outcomes between the firstand second-generation of Muslim immigrants both in terms of female education and fertility. Earlier work by Rooth and Ekberg (2003) using Swedish data shows that second-generation immigrants who are descendants of mixed marriages with natives perform better in the labor 
market (in terms of unemployment) than second-generation immigrants without a native background.

We extend previous work by investigating immigrant groups by generation and by source country, focusing specifically on the relative importance of family size on education for $16 / 17$ to 20-year-old immigrants and natives in France and Germany. The hypothesis of a quantity-quality trade-off related to family size and children's educational outcomes rests on the idea that a limited amount of resources is available for any number of children in the family such that the resources per child, and hence the "quality" measured as educational achievement, declines with the number of siblings (a resource dilution model). Early theoretical statements of this hypothesis in the field of economic demography appeared in Becker and Lewis (1973) and Becker and Tomes (1976) and were followed by Blake's (1981) initial empirical analyses of the relation between children's educational outcomes (years of schooling) or intelligence test results (IQ) and number of siblings. Although Blake's (1981) results are based primarily on whites in the U.S., she also discusses evidence for European countries (including France). Despite some variation across data sets and countries, she finds overall that children in families with three or more children have lower educational outcomes, whereas only children and children with one sibling differ little. Hanushek (1992) confirms this negative relationship between school test results and the number of children in a family but stresses the need to control for confounding factors (e.g., income) that may be correlated with family size and lead to biased estimates of the quantityquality trade-off. A recent paper documents a quantity-quality trade-off among secondgeneration immigrants in Germany by using the introduction of birthright citizenship as exogenous variation in the "price of quality" (Avitabile et al. 2014). However, "quality" is not measured by education but by health outcomes. 
The observational data on the quantity-quality trade-off used here, however, can only be expected to represent the locus of optimal quantity-quality choices of a population that is heterogeneous in terms of both the shape of the quantity-quality trade-off (which may be regarded as a "budget constraint") and the preferences for the quantity and quality of children. Hence, note that control variables, as used by Hanushek (1992) and in our study, may only partially control for heterogeneity in estimating the quantity-quality trade-off. ${ }^{2}$

Keeping in mind this limitation, our estimates of the quantity-quality trade-off, based on regression adjustment, indicate that there is some trade-off for families with at least two children, especially when the number of children in the family exceeds three. It seems, therefore, that reduced fertility allows immigrants to raise their children's educational outcomes through a potential quantity-quality trade-off. Nevertheless, the estimated quantity-quality loci differ between natives and immigrants, with the latter usually lagging behind, especially when they belong to the first generation of immigrants and come from source countries like Turkey or Middle Eastern nations. This result corresponds to Georgiadis and Manning's (2011) findings for the UK. Once we control for parental background (by education and income), however, we find that between one third and the complete difference in family-size adjusted educational outcomes

\footnotetext{
${ }^{2}$ For this reason, many recent studies in economic demography estimate the quantity-quality trade-off using exogenous shocks to family size. The most prominent approach is to use twin births or same-sex siblings to generate exogenous variation in childbirth (using an instrumental variable strategy), a method adopted by Angrist, Lavy and Schlosser (2010), Åslund and Grönqvist (2010), Black, Devereux and Salvanes $(2005 ; 2010)$ and Conley and Glauber (2006) in their studies of industrialized countries. These studies, however, find either no or only minor quantity-quality trade-offs (at least compared to OLS estimates), with larger effects for economically disadvantaged families ( $\AA$ slund and Grönqvist 2010) and negative effects for later-born children ( $₫$ slund and Grönqvist 2010; Black, Devereux and Salvanes 2005; Conley and Glauber 2006). Angrist, Lavy and Schlosser (2010) show that these effects can be explained by families developing strategies to increase the resources devoted to children (i.e., parents shift their own consumption to their children's consumption). Black, Devereux and Salvanes (2010) do find significant effects of family size on IQ when twin births (rather than same-sex siblings) are used as the instrument, which might suggest that unplanned additional births have negative effects on children's outcomes. However, Rosenzweig and Zhang (2009), using Chinese data, point out that estimates based on twin-birth instruments are biased upward in absolute value because of the specificity of resource competition between twins both biologically and materially compared to non-twin siblings. Nevertheless, these authors do identify a quantity-quality trade-off for China but again suggest that the effects of the one-child policy-induced by this trade-off-are small.
} 
between both first- and second-generation immigrants and immigrants from different source countries disappear. Indeed, Blinder-Oaxaca decompositions demonstrate that parents' educational background accounts for the largest share in the explained higher education track attendance gap between natives and immigrants. Differences in the number of siblings (or differences in parental income, depending on the specification) account for the second (or third) most important contribution to the explained gap. These findings hold true in both France and Germany, two major European economies with distinct colonial and immigration histories.

The remainder of the paper is structured as follows: Section 2 describes the data sets used for France and Germany, based on which Section 3 gives a first descriptive overview. Section 4 explains the methodology. Section 5 provides Blinder-Oaxaca decompositions for the higher education track attendance gap followed by a more detailed look at simulated quantity-quality loci for immigrants of different source countries and immigrant generations in Section 6. Section 7 concludes.

\section{Data}

Our analysis is based on survey data containing information on first- and secondgeneration immigrants, as well as on household composition and education participation. Specifically, we use data from the French Labor Force Survey (Enquête de l'Emploi, 2006, 2007, 2008 and 2009) ${ }^{3}$, the German Microcensus ${ }^{4} 2005$ and 2008 and - to increase the sample size for

\footnotetext{
${ }^{3}$ The French Labour Force Survey is a representative survey of the French population. The survey is conducted quarterly by the National Institute of Statistics and Economic Studies (INSEE) and consists of around 57,000 different households containing around 108,000 respondents aged at least 15 years in each year (INSEE 2010).

${ }^{4}$ The German Microcensus is an annual household survey that is representative for the German population. Participation in the survey is mandatory. We use the scientific use file (SUF) of the German Microcensus, which is a $0.7 \%$ sample of the German population and contains about 480.000 observations per year.
} 
Germany - the German Socio-Economic Panel (GSOEP) 2000-2009. ${ }^{5}$ Sampling weights are adjusted, however, so that the averages of the weighting variable are the same across the three data sets German Microcensus 2005, 2008, and the GSOEP. This ensures that each observation on average has same importance irrespective of the data sets it comes from, without changing the relative weights of observations within a data set.

The key variables needed for the analysis are current education track, siblings in the household, and identifiers for first- and second-generation immigrants as well as immigrants' origin. ${ }^{6}$ First generation immigrants at this age generally arrived during their childhood (on average at the age of 9 in the French sample and at 7 years in the German sample). Thus, they received a large part of their education in the host country. To enable measurement of the education track attended, we restrict our sample to adolescents aged between 16 and 20 years for France and between 17 and 20 years for Germany (because education track data for German middle school students is unavailable; cf. Kristen and Granato, 2007, who consider 18 year olds, and Luthra, 2010, and Gresch and Kristen, 2011, who consider 18-20 year olds). In France, since the introduction of the comprehensive collège unique, pupils are also no longer tracked in middle school. However, after the end of middle school, when students are about 14/15 years old, some go on to a senior high school (lycée) to earn a university entrance certificate (baccalauréat général or technologique). We therefore define these students (or those already attending university or other higher educational institutions) as higher track students and other students, primarily those working towards a vocational degree like the certificat d'aptitude professionnelle

\footnotetext{
${ }^{5}$ The GSOEP is a longitudinal study of private households in Germany. The panel has been existing since 1984 and currently contains representative information of nearly 12,000 households per year (Wagner et al. 2007). To identify first-and second-generation immigrants and their origin in the GSOEP, we use data from the years 19842009. In the subsequent empirical analysis, we use only the more recent years 2000-2009.

${ }^{6}$ Because the major immigration waves only began in the 1950s and 1960s, the third generation, although identified, is still so young so that the average number of siblings in the household is underestimated compared to the observations for first- and second-generation immigrants.
} 
(C.A.P.) or baccalauréat professionnel, as lower track students. In Germany, on the other hand, students are considered to be on the higher track if they are attending a school that leads to a university entrance qualification (e.g., Gymnasium or Fachoberschule) or are already attending university or college (Universität or Fachhochschule). The shares of high track students (as defined above) are 58\% in France and $47 \%$ in Germany (for shares by generation and source country group see Table 1$)^{7}$

Every individual in the specified age group 16/17-20 is an observation in the sample, but for each person, we also measure the number of siblings in the household irrespective of sibling age (in the regressions below, we cluster standard errors at the household level). Because the socio-economic surveys at our disposal do not ask adults how many siblings they have, however, we are forced to determine the number of siblings by sampling the number of children present in the household (the number of children ever born to a mother is only observed in the Microcensus 2008; we use this variable in a robustness check below). Such sampling does of course generate measurement error for children whose siblings have already left the household or whose siblings are not yet born. Nevertheless, the expected value of siblings not observed in a household should be positively correlated with the number of children residing in the household. Hence, despite some potential measurement error, we hope to derive meaningful empirical relations between family size and the children's education track attendance that can be compared across source country groups and immigrant generations. If the measurement error is similar across compared groups, the group comparisons are unbiased. Indeed, using data from the Microcensus 2008, we can compare the total number of children ever born to a mother with the number of children in the household. Focusing on mothers with children aged between 16 and 20 years (the group we

\footnotetext{
${ }^{7}$ For a discussion of the potential implications of the education track choice for subsequent labor market outcomes, see Dustmann (2004). For a further description of the German school tracking system, see, for example, Mühlenweg and Puhani (2010).
} 
consider in our sample), we find that the number of children born is 0.37 larger than the one we measure; it is 0.35 children larger for natives, 0.40 children larger for Western Europeans, 0.35 children larger for Eastern Europeans, 0.60 children larger for families with Turkish origin, and 0.53 children larger for ethnic Germans. Hence, for all ethnic groups, we are not missing more than one child on average. Using data from the Microcensus 2008, we will show below that our main results are similar when using information on the number of children ever born to a mother to build the variable on the number of siblings.

Because we analyze education track attendance and family size by the immigrants' source country group, we also attempt to harmonize the source country definitions for France and Germany. We must also, however, take into account given country groupings in the respective data sets, as well as national specificities like the large-scale immigration of ethnic Germans from Eastern Europe into Germany since the fall of the Iron Curtain. Hence, for France, we distinguish between immigrants from Western Europe, Eastern Europe, Turkey/Middle East, Africa and others, and for Germany, those from Western Europe, Eastern Europe (excluding ethnic Germans), Turkey, Africa/Middle East, ethnic Germans (from Eastern Europe including the former Soviet Union) and others. ${ }^{8}$

We further distinguish between natives and first- and second-generation immigrants according to their own and their parents' country of birth. Irrespective of the citizenship status, we define first-generation immigrants as foreign-borns of France and Germany, respectively, and second-generation immigrants as native-borns with at least one parent who is a first-generation immigrant. ${ }^{9}$ Natives are born in France or Germany with French or Germany citizenship, respectively, and have non-immigrant parents. Unfortunately, for most source country groups,

\footnotetext{
${ }^{8}$ For the definition of ethnic Germans see the Data Appendix.

${ }^{9}$ Since we exclude expatriates from the former French territories overseas, first-generation immigrants to France are defined as foreign-borns who had no French citizenship at birth.
} 
sample size allows no distinction based on family size for both source country and immigrant generation (first versus second) at the same time, so that we cannot make these distinctions simultaneously. ${ }^{10}$ Such distinction is only possible for the largest source country groups; that is, immigrants from Africa and Turkey in France and Germany, respectively.

\section{$3 \quad$ Number of Siblings and Higher Track Attendance - Overview}

Figure 1 plots the share of students on the higher education track against the average number of siblings for natives, first- and second-generation immigrants from different source country groups. For natives, the share of students on the higher education track is about $59 \%$ in France (Figure 1a) and 47\% in Germany (Figure 1b). The average number of siblings for a student in the sample is 1.4 and 1.1 in France and Germany, respectively (corresponding to a family size of 2.4 and 2.1, respectively), which reflects the higher fertility in France compared to Germany. In both France and Germany, the point estimate for the share of students on the higher education track is highest for natives: only some immigrant generations of Western and Eastern European immigrants exhibit larger shares. Natives also have the smallest number of siblings in both countries (with the exception of Eastern European immigrants).

Figure 1 also illustrates how-over the generations-immigrants have integrated into their host societies by converging towards native outcomes in terms of both higher education track attendance and family size. This holds especially for immigrants from Turkey and the Middle East in France. First-generation immigrants from Turkey/the Middle East have 3.2 siblings compared to the native average of 1.2 siblings, but this number decreases to 2.1 in the second generation. The fertility gap is thus halved within one generation. Also the share of

\footnotetext{
${ }^{10}$ For numbers of observations by immigrant generation and source country group see Table A1; for the sample means see Table A2 in the Appendix.
} 
people on the high education track increases from 13\% among first generation immigrants from Turkey/Middle East to 38\% among the second generation. Immigrants from Africa, on the other hand, on average have 2.2 siblings in both the first and the second generation. However, the share of people on the high education track increases from $38 \%$ in the first generation to $55 \%$ in the second generation among this source country group. For immigrants to Germany, the picture is similar: natives have 0.9 siblings on average, whereas immigrants from Turkey have 2.4 and 1.7 siblings in the first and second generation, respectively. What is interesting here is that Turkish immigrants seem to have higher fertility in France, where fertility is generally high by European standards, than in Germany, where it is generally low. ${ }^{11}$ European immigrants are already fairly close to natives as regards fertility from the first generation onwards in both France and Germany. Hence, these results are consistent with Stichnoth and Yeter's (2013) findings that whereas first-generation immigrants have fertility rates similar to their source countries, the second generation already exhibits fertility rates much closer to the receiving country.

\section{$4 \quad$ Methodology}

Because immigrant groups may differ by parental educational background and income, we also investigate whether the difference between source country groups can be explained by differences in socio-economic — rather than purely cultural—background. In particular, we use linear probability models to estimate regressions of higher education track attendance on the

\footnotetext{
${ }^{11}$ The figures for Turkey are roughly consistent with those in Table 17 of Constant, Nottmeyer, and Zimmermann (2009), which reports 3.17 and 2.00 children for first- and second- generation Turkish mothers who are at least 40 years old. It should be noted, however, that (depending on place of birth) these children could be first/second- or third-generation immigrants. In our study, we find 2.4 siblings - that is, 3.4 children - in the second generation, which corresponds to the 3.17 children reported by those authors.
} 
number of siblings, while including indicators of parental educational background, family income categories, gender, age and time dummies as control variables. ${ }^{12}$

Based on these regressions, in which the regression coefficients are estimated separately by each source country group, we first carry out Blinder-Oaxaca decompositions to account for the contribution of the different sets of $K$ explanatory variables $X_{k}$ to the explained gap in higher education track attendance rates between natives and different types of immigrants (defined by source country group and generation). ${ }^{13}$ More precisely, we estimate regressions of the form

$$
\text { HigherEducationTrack }_{i}=\sum_{k=1}^{K} \beta X_{k i}+\varepsilon_{i}
$$

separately for natives and for different immigrant groups. We then decompose the gap in average higher education track attendance between natives and the respective immigrant group, based on natives' coefficients. In our first set of results, we only report decompositions based on natives' coefficients, because (i) natives are the largest group and thus will yield the most stable coefficient estimates and because-contrary to the classic Blinder Oaxaca decomposition for just two groups in total-(ii) we have more than just one alternative when choosing the coefficients of an immigrant group. This is because immigrant groups are distinguished by immigrant generation and source country, thus yielding several alternative decompositions. The decomposition based on natives' coefficients is thus more suited in comparing weighted sums of control variable endowments between different immigrant groups in relation to natives and is defined as follows:

\footnotetext{
${ }^{12}$ Probit models yield similar results.

${ }^{13}$ Non-linear decomposition results according to Yun (2004) yield similar results.
} 


$$
\begin{aligned}
& \overline{\text { HigherEducationTrack }}_{\text {native }}-\overline{\text { HigherEducationTrack }}_{\text {immigrant }}= \\
& \underbrace{\sum_{k=1}^{K} \hat{\beta}_{k, \text { native }}\left(\bar{X}_{k, \text { native }}-\bar{X}_{k, \text { immigrant }}\right)}_{\text {explained gap }}+\underbrace{\sum_{k=1}^{K}\left(\hat{\beta}_{k, \text { native }}-\hat{\beta}_{k, \text { immigrant }}\right) \bar{X}_{k, \text { immigrant }}}_{\text {unexplained gap }}
\end{aligned}
$$

We calculate this decomposition for natives and alternative immigrant groups, defined by immigrant generation and source country, thus yielding a set of pairwise decompositions. Explanatory variables $X$ are the number of siblings, parental educational background, parents' income, age, gender, and calendar year dummy variables.

The purpose of these Blinder-Oaxaca decompositions is to gauge the relative importance of the number of siblings compared to the other control variables (like parental education or income) in explaining the gap in higher education track attendance rates between natives and different types of immigrants.

In order to take a closer look at the differences in the association of higher education track attendance and family size between natives and immigrants, we calculate higher education track attendance rates by number of siblings and immigrant groups. In addition to reporting these statistical associations unconditionally, we also carry out a simulation, where we keep all control variables (parental background, gender, age, time) at the native sample means $\bar{X}_{\text {native }}$ and combine them with the immigrant-specific regression coefficients as follows: ${ }^{14}$

$$
\begin{aligned}
& E\left[\text { HigherEducationTrack } \mid \# \text { siblings, } \bar{X}_{\text {native }}\right]= \\
& \hat{\beta}_{\text {siblings,immigrant }}(\# \text { siblings })+\sum_{k=2}^{K} \hat{\beta}_{k, \text { immigrant }} \bar{X}_{k, \text { native }}
\end{aligned}
$$

An analogous simulation will be carried out for natives:

\footnotetext{
${ }^{14}$ To keep notation simple, the vector $X$ includes the number of siblings as a regressor in equations (1), (2) and (4), but excludes it in equation (3), where we single out the variable "number of siblings" to illustrate our simulation.
} 


$$
\begin{aligned}
& E\left[\text { HigherEducationTrack } \mid \# \text { siblings, } \bar{X}_{\text {native }}\right]= \\
& \hat{\beta}_{\text {siblings,native }}(\# \text { siblings })+\sum_{k=2}^{K} \hat{\beta}_{k, \text { native }} \bar{X}_{k, \text { native }}
\end{aligned}
$$

These "conditional higher track attendance" rates thus simulate the immigrant group's higher track attendance rates separately for each sibling number, based on the supposition that immigrants had characteristics equal to natives, for example the same average parental background. Presenting the conditional higher track attendance graphically illustrates the locus of the potential quantity-quality trade-off for natives and different immigrant groups, holding the other control variables constant at native means.

The pairwise difference between natives and any immigrant group in this simulation equals the unexplained educational gap between natives and the respective immigrant group in the Blinder-Oaxaca decomposition alternative to equation (2), where this unexplained gap is determined separately for each number of siblings. This "alternative" to decomposition (2), which is defined as

$$
\begin{aligned}
& \overline{\text { HigherEducationTrack }}_{\text {native }}-\overline{\text { HigherEducationTrack }}_{\text {immigrant }}= \\
& \underbrace{\sum_{k=1}^{K} \hat{\beta}_{k, \text { immigrant }}\left(\bar{X}_{k, \text { native }}-\bar{X}_{k, \text { immigrant }}\right)}_{\text {explained gap }}+\underbrace{\sum_{k=1}^{K}\left(\hat{\beta}_{k, \text { native }}-\hat{\beta}_{k, \text { inmmigrant }}\right) \bar{X}_{k, \text { native }}}_{\text {unexplained gap }}
\end{aligned}
$$

is more suited to comparing weighted sums of unexplained gaps between natives and different immigrant groups, because it always uses the same weights, namely the native sample means $\bar{X}_{\text {native }}$, in order to compare the unexplained gap. If the complete difference in the educational gap between natives and immigrants were explained by our control variables, the graphs of these "conditional higher track attendance" rates would be the same for natives and immigrants. 


\section{The Contribution of the Number of Siblings in Explaining the Educational Gap between Natives and Different Groups of Immigrants}

Table 2 presents the total gap, the explained gap, as well as the components of the explained gap for different types of explanatory variables, here denoted by $k$ as determined by the Blinder-Oaxaca decomposition described in equation (2) (alternative decompositions, where differences in characteristics are evaluated at immigrants' coefficients, are presented in Table A3). The decompositions are carried out for different immigrant groups, so that each column in the table represents an immigrant group and the corresponding decomposition between natives and the respective immigrant group. ${ }^{15}$ The first two columns define immigrant groups by immigrant generation (first and second generation), the subsequent columns distinguish immigrants by source country groups. Sample size restrictions prevent us from defining further subgroups that distinguish both immigrant generation and source country group. The top panel reports results for France, the bottom panel reports results for Germany.

Looking at the first two columns first, we observe that the gap between natives and first and second generation immigrants in higher education track attendance shrinks significantly between the first (16 and 12 percentage point gap in France and Germany, respectively) and the second generation (4 and 5 percentage point gap for France and Germany, respectively) in both France and Germany. The share of the explained gap in the Blinder-Oaxaca decomposition varies from slightly less than half to more than twice the observed gap. This means that differences in observed characteristics explain a large part or even "overexplain" the higher education track attendance gap. This finding echoes that of Liebig and Widmaier (2009), who show that, in terms of the PISA scores of immigrants in OECD countries, controlling for socioeconomic background reduces educational gaps between immigrants and natives by half. It is

\footnotetext{
${ }^{15}$ See Table A4 of the Appendix for the full regression results.
} 
also consistent with previous evidence for Germany by Kristen and Granato (2007), Luthra (2010), and Gresch and Kristen (2011) who find-based on regression adjustment — that social background (here education, occupational status, and in the first two also income of parents and number of siblings) explain or even "overexplain" (the latter especially for the second generation) educational gaps between natives and various immigrant ethnicities (this "overexplaining" also occurs in the alternative decompositions based on immigrants' coefficients, displayed in Table A3 in the Appendix).

When we account for the contributions of different explanatory variables to the explained gap (the elements of the sum of the first term on the right-hand side of equation (2)), we find that for second-generation immigrants in France and first- and second-generation immigrants in Germany, parents' educational background, followed by the number of siblings and parents' income contribute most to the explained gap, with parents' educational background explaining the largest share. ${ }^{16}$ For the Netherlands, Van Ours and Veenman (2003) also find that differences in educational attainment between source country groups and natives mostly disappear when the parental educational background is taken into account. However, our decomposition demonstrates that the number of siblings also plays an important role and explains about a quarter of the explained gap between natives and first- and second-generation immigrants in France and in Germany.

When distinguishing immigrants by source country groups (the third through the sixth columns in Table 2), the decompositions exhibit some idiosyncrasies, but at least for the largest immigrant groups (Africans in France and Turks in Germany), we find a similar result to the

\footnotetext{
${ }^{16}$ With some exceptions, this finding is still valid when the coefficients of the immigrant groups are used to evaluate the gap in average characteristics between natives and immigrants, see Table A3 in the Appendix. Note that because of smaller sample sizes of the immigrant groups, their coefficients are estimated with less precision, so that we prefer the decompositions based on natives' coefficients as exhibited in equation (2).
} 
above: our explanatory variables overexplain the higher education track attendance gap between natives and these immigrant groups. Differences in parents' educational background contribute the largest share to the explained gap in both France and Germany. The number of siblings contributes the second largest share of the explained gap in Germany. In France, the number of siblings is also the second most important explaining factor for immigrants from Africa, the largest immigrant group, while for the remaining immigrant groups parental income contributes the second largest share of the explained gap with natives.

Because most of our data sources only allow us to measure the number of siblings based on the number of children present in the household, the question arises whether this potential measurement error generates significant bias. In order to address this concern, we alternatively make use of information in the Microcensus 2008 on the number of children ever born to a mother in order to calculate the number of siblings variable. The corresponding decomposition results are reported in Table A5. When comparing these results with the estimates based on all German data in Table 2, we find that they are at least similar.

Another concern with the way we measure the number of siblings is that the older children are, the more likely they are to leave the household. Especially if leaving the household is correlated with participating in the higher education track and/or ethnic group, this might lead to bias. Because the vast majority of children still remain in the household up to the age of 18 , we present decomposition results for both France and Germany based on a restricted sample of children aged only up to 18 (instead of 20) years (cf. Luthra, 2010, footnote 7). The corresponding decomposition results are shown in Table A6. Comparing these results with our main estimates in Table 2, we find them to be very similar. Due to these robustness results, we will continue to work with our larger sample below. As the link between family size and 
educational decisions is the focus of this paper, we take a closer look into this relationship for natives and different groups of immigrants in the following.

\section{Education Track Attendance and Family Size Across Generations of Immigrants and Across Immigrants of Different Source Countries}

\subsection{First- and Second-Generation Immigrants}

To compare the quantity-quality locus of natives with those of first- and secondgeneration immigrants while still preserving large enough samples, we combine immigrants from all source country groups, graph the unconditional relations in Figure 2, the conditional relations in Figure 3 and then, in Section 6.2, present separate results for the largest source country groups (African countries in France, Figure 4a; Turkey in Germany, Figure 4b). Although a lack of random variation in family size (or cost of education) prevents an estimation of the quantityquality trade-off per se, we can still describe the empirical relationship between higher education track attendance and the number of siblings. ${ }^{17}$

In line with some of the evidence by Blake (1981), we find that children with no siblings have slightly worse outcomes than children with one sibling. For students with at least one sibling or more, we find mostly that the higher education track attendance rate decreases with the number of siblings, particularly, if the number of siblings is three or more. This observation

\footnotetext{
${ }^{17}$ Because we do not observe random shocks to family size in this study, we cannot claim that the association between the number of siblings and education track attendance is causal: differences in unobserved educationrelevant family characteristics that correlate with family size may lead to biased estimates of the quantity-quality trade-off. Nevertheless, the survey data used here provide us with such a rich set of socio-economic background characteristics that many can be held constant in a regression model. To distinguish the causal quantity-quality trade-off from the regression-adjusted estimates meant to proxy this trade-off, we use the term "quantity-quality locus".
} 
holds true for both France and Germany and for all three groups considered-natives, firstgeneration and second-generation immigrants.

It is also worth noting that the quantity-quality locus for natives lies mostly above the loci for first- and second-generation immigrants, but that second-generation immigrants catch up to almost native levels, more so in France than in Germany. In both countries, once the number of siblings is held constant, second-generation immigrants are more likely than first-generation immigrants to attend the higher education track. For natives, this likelihood is even higher than for second-generation immigrants, although for France the difference between natives and second-generation immigrants is small.

In Figure 3, we apply the simulation shown in equation (3) and exhibit the regressioncontrolled quantity-quality loci (see Table 3 for the regression results). As the figure illustrates, once we account for differences in parental background and income (among other variables), the quantity-quality trade-offs for natives, first- and second-generation immigrants move closer together. For France, the regression-adjusted higher education track attendance of secondgeneration immigrants is now even above that for natives for a given number of siblings (Figure 3a).

\subsection{A Closer Look at Africans in France and Turks in Germany}

This latter finding becomes even more pronounced when we consider the largest immigrant groups separately (Africans in France and Turks in Germany, see Figure 4). It shows that second-generation African immigrants in France outperform natives, even more than the average second-generation immigrant (Figure 4a). When immigrants with Turkish origin are analyzed by generation a different picture emerges for Germany (Figure 4b): although born in 
Germany, second-generation Turkish immigrants still lag behind natives in higher education track attendance.

This means, conditional on family size and holding parental background characteristics constant, the largest immigrant group in France, African immigrants, performs better than the average immigrant, whereas the largest immigrant group in Germany, Turkish immigrants, performs worse than the average immigrant. However, when we look at the conditional means (the points in Figure 4b), we nevertheless see a clear convergence of second-generation Turkish immigrants towards natives compared to the first generation: the predicted mean number of siblings is lower than the number for first-generation immigrants and the predicted average of high education track attendance is higher.

\subsection{Immigrants of Different Source Countries}

Since in most cases immigrants catch up with natives in terms of participation in a higher education track and/or fertility (as we showed above), we now investigate the association between quality of education and quantity of children separately for immigrant groups defined by source country. Figures $5 \mathrm{a}$ and $5 \mathrm{~b}$, which represent "unconditional" (i.e. raw) data without regression adjustment, illustrate this relation for different source country groups in France and Germany, respectively. Overall, more children in the family are associated with a lower incidence of higher education track attendance. However, there are several cases in which the relation appears flat, suggesting no trade-off between the quantity and quality of children. The graphs further show significant gaps between the quantity-quality loci for different source country groups. In other words, even if we hold the number of children in the household constant, educational levels differ by source country origin. 
In both France and Germany, natives have the highest rates of higher education track attendance given the same number of siblings in the household (with the exception of immigrants from Eastern Europe with zero or one siblings in France). Immigrants from Western and Eastern Europe, and also — in the case of Germany — from Africa and the Middle East, have rates similar to those of natives for a given number of siblings in the family. However, immigrants from Turkey (and the Middle East) almost consistently exhibit the lowest higher education track attendance rates of the groups investigated here.

In Figure 6, we simulate the conditional higher education track attendance rates by source country group, as defined in equations (3a) and (3b). A comparison of the conditional (Figure 6) with the unconditional graph (Figure 5) shows that, when the number of siblings is held constant, our socio-economic control variables explain about a third to a half of the variation (range) in the higher education track attendance among source country groups (a finding that is in line with the results of the Blinder-Oaxaca decompositions, but note that each graph summarizes several simulations in one panel). Similar to Van Ours and Veenman (2003), who show that firstgeneration immigrants from Turkey and Morocco still underperform compared to natives in the Netherlands, even when parental education is held constant, we find such underperformance for Turkish and repatriated ethnic Germans, but not for African immigrants to Germany (Figure 6b). In France, African (including North African Arab) immigrants outperform natives when both family size and parental background are held constant (Figure 6a). Furthermore, we find that for both France and Germany, once socio-economic background characteristics are controlled for, higher education track attendance barely varies with the number of children in a household. Only if there are three or more siblings (i.e., at least four children in the household) higher education track attendance is lower. Although the average number of siblings is higher in France, having 
three or more siblings is more strongly correlated with a lower probability of being on the high education track in France than in Germany.

When we analyze boys and girls separately (results not shown here, but available non request) we find, in line with recent empirical evidence in the (economics of) education literature, that girls outperform boys. Interestingly, we detect no systematic relative disadvantage for girls versus boys from predominantly Muslim countries in terms of higher education track attendance.

\subsection{Controlling for having Mixed-Couple Parents}

As shown by Rooth and Ekberg (2003), second-generation immigrants who have one native parent perform better in the labor market than second-generation immigrants with two immigrant parents. Having intermarried parents could also have a positive effect on the education of the child compared to having two immigrant parents. This might have different reasons: first children with a native parent are less likely to have a foreign language as mothertongue compared to children with two immigrants parents (Stevens, 1985), second, mixed couples tend to have higher earnings (as shown for example by Meng and Meurs, 2009) and third, better educational outcomes may be achieved through better knowledge of the educational system and networks (composed of natives) of the native parent. On the other hand, Furtado (2009) argues that inter-ethnic parents may be less efficient in parenting (due to coordination and bargaining costs) or have lower aspirations for their children (as the need to assimilate by working hard might feel less pressing because the inter-ethnic marriage itself is already a significant display of assimilation).

The share of second-generation immigrants whose parents constitute a mixed marriage varies significantly by source country in our sample. That is, although this share is as high as 
66\% and 51\% for Western Europeans in France and Germany, respectively, it is only 24\% and $20 \%$ for Africans and as low as $17 \%$ and $1 \%$ (sic) for Turks in France and Germany, respectively. ${ }^{18,19}$

Hence, to check whether the low rate of intermarriage with natives among Turks explains part of the remaining gap between the quantity-quality loci of natives and Turks (Rooth and Ekberg, 2003), we add an indicator for being a child of mixed parentage to the set of control variables $X$ and redo the simulations defined by equation (3). We find that, controlling for mixed marriages of the parents makes hardly any difference to our results. ${ }^{20}$ A possible explanation for the difference compared to the results of Rooth and Ekberg (2003) could be that Rooth and Ekberg do not control for household income and education of the parents. Although Furtado (2009) reports that second-generation immigrant children of mixed parents have lower probabilities to drop out of high school compared to second-generation immigrants with two foreign-born parents in the US, the relationship reverses in sign when she controls for parental education and income.

\section{Conclusions}

In this paper, we provide empirical evidence for an association between the number of children in a family and higher education track attendance for natives and for first- and secondgeneration immigrant children in France and Germany. Hence, extending previous studies, our

\footnotetext{
${ }^{18}$ See Table A7 of the Appendix. In the French sample, immigrants from Turkey must be grouped together with immigrants from the Middle East. Due to data limitations it is not possible to distinguish these groups in the second generation. According to census data of 1999, among married Turkish immigrants $14 \%$ of Turkish men and $4 \%$ of Turkish women were intermarried (INSEE 2005).

${ }^{19}$ Constant, Nottmeyer, and Zimmermann (2009) also find very low intermarriage rates for Turkish immigrants to Germany, reporting intermarriage rates of first-generation Turkish women and men of 1.94 and 5.79, respectively (see their Table 11).

${ }^{20}$ See Table A8 of the Appendix for the regression results.
} 
analysis links the catch-up process from the first- to the second-immigrant generation to the alleged trade-off between the quantity of children and the quality of their education.

Our three main findings are the following. We observe that (i) children with two or more siblings have lower probabilities to be on the high education track compared to children with fewer siblings (potential quantity-quality trade-off) in both France and Germany. Furthermore, we find that (ii) immigrants do indeed catch up over the generations both through reduced fertility (which allows their offspring to attain higher educational levels, especially if the number of children in the family is less than four) and by way of a pure catch-up process that occurs even when family size is held constant. Blinder-Oaxaca decompositions demonstrate that (iii) although differences in family size account for a significant share of the explained gap in higher education track attendance between natives and immigrants, parents' educational background accounts for the largest share of the explained gap, mostly followed in explanatory importance by the number of children in the family and parents' income. 


\section{References}

Algan, Y., Dustmann, C., Glitz, A. and Manning, A. (2010) The Economic Situation of First and Second-Generation Immigrants in France, Germany and the United Kingdom. Economic Journal, 120 (542), F4-F30.

Angrist, J. D., Lavy, V. and Schlosser, A. (2010) Multiple Experiments for the Causal Link between the Quantity and Quality of Children. Journal of Labor Economics, 28 (4), $773-823$.

Åslund, O. and Grönqvist, H. (2010) Family Size and Child Outcomes: Is There Really No Trade-off?. Labour Economics, 17 (1), 130-139.

Avitabile, C, Clots-Figueras, I. and Masella, P. (2014) Citizenship, Fertility, and Parental Investments. American Economic Journal: Applied Economics, 6 (4), 35-65.

Becker, G. S. and Lewis, H. G. (1973) On the Interaction between the Quantity and Quality of Children. Journal of Political Economy, 81 (2), 279-288.

Becker, G. S. and Tomes, N. (1976) Child Endowments and the Quantity and Quality of Children. Journal of Political Economy, 84 (4); 143-162.

Black, S. E., Devereux, P. J., and Salvanes, K. G. (2005) The More the Merrier? The Effect of Family Size and Birth Order on Children's Education. Quarterly Journal of Economics, $120(2), 669-700$.

Black, S. E., Devereux, P. J., and Salvanes, K. G. (2010) Small Family, Smart Family? Family Size and the IQ Scores of Young Men. Journal of Human Resources, 45 (1), 33-58.

Blake, J. (1981). Family Size and the Quality of Children. Demography, 18 (4), 421-442. 
Blau, F. D., Kahn, L. M., Liu, A. Y-H., and Papps, K. L. (2013) The transmission of women’s fertility, human capital and work orientation across immigrant generations, Journal of Population Economics, 26 (2), 405-435.

Card, D., Dustmann, C. and Preston, I. (2012) Immigration, Wages, and Compositional Amenities, Journal of the European Economic Association, 10 (1), 79-119.

Conley, D. and Glauber, R. (2006) Parental Educational Investment and Children's Academic Risk: Estimates of the Impact of Sibship Size and Birth Order from Exogenous Variation in Fertility, Journal of Human Resources, 41 (4), 722-737.

Constant, A. F., Nottmeyer, O. and Zimmermann, K. F. (2012) Cultural Integration in Germany. in: Algan, Y., Bisin, A., Manning, A. and Verdier, T. (Ed.), Cultural Integration of Immigrants in Europe. Oxford: OUP.

Dustmann, C. (2004) Parental Background, Secondary School Track Choice and Wages. Oxford Economic Papers, 56 (2), 209-230.

Furtado, D. (2009) Cross-Nativity Marriages and Human Capital Levels of Children. Research in Labor Economics, 29, 273 - 296.

Gang, I. N. and Zimmermann, K. F. (2000) Is Child Like Parent? Educational Attainment and Ethnic Origin. Journal of Human Resources, 35 (3), 550-569.

Georgiadis, A., and Manning, A. (2011) Change and Continuity among Minority Communities in Britain. Journal of Population Economics, 24 (2), 541-568.

Gresch, C. and Kristen, C. (2011) Staatsbürgerschaft oder Migrationshintergrund? Ein Vergleich unterschiedlicher Operationalisierungsweisen am Beispiel der Bildungsbeteiligung, Zeitschrift für Soziologie 40 (3), 208-227. 
Hanushek, E. A. (1992) The Trade-off between Child Quantity and Quality. Journal of Political Economy, 100 (1), 84-117.

INSEE (2005) Les immigrés en France: Population Immigrée - Qui et combien? Histoire et origines ; Vie familiale, Édition 2005, Paris.

INSEE (2010) Sources and methods. Continuous Labour Force Survey (as of 2003) http://www.insee.fr/fr/methodes/sources/pdf/methodologie_eeencontinu_anglais.pdf INSEE (2012) Immigrés et descendants d'immigrés en France - Insee Références - Édition 2012, Paris.

Kristen, C. and Granato, N. (2007) The Educational Attainment of the Second Generation in Germany, Social Origins and Ethnic Inequality. Ethnicities, 7 (3), 343-366.

Liebig, T. and Widmaier, S. (2009) Children of Immigrants in the Labour Markets of EU and OECD Countries: An Overview, OECD Social, Employment and Migration Working Papers No. 97.

Luthra, R. R. (2010) Assimilation in a New Context: Educational Attainment of the Immigrant Second Generation in Germany, Discussion Paper No. 2010-21, Institute for Social and Economic Research, University of Essex.

Meng, X. and Meurs, D. (2009) Intermarriage Language and Economic Assimilation Process: a Case Study of France. International Journal of Manpower, 30 (1/2), 127-144.

Milewski, N. (2010) Immigrant fertility in West Germany: Is there a socialization effect in transitions to second and third births? European Journal of Population, 26 (3), 297-323.

Mühlenweg, A. M. and Puhani, P. A. (2010) The Evolution of the School Entry Age Effect in a School Tracking System. Journal of Human Resources, 45 (2), 407-438. 
Riphahn, R. (2003) Cohort Effects in the Educational Attainment of Second Generation Immigrants in Germany: An Analysis of Census Data. Journal of Population Economics, $16(4), 711-737$.

Rooth, D.-O. and Ekberg, J. (2003) Unemployment and Earnings for Second Generation Immigrants in Sweden. Ethnic Background and Parent Composition. Journal of Population Economics, 16 (4), 787-814.

Rosenzweig, M. and Zhang, J. (2009) Do Population Control Policies Induce More Human Capital Investment? Twins, Birthweight, and China's One Child Policy. Review of Economic Studies, 76 (3), 1149-1174.

Sarrazin, T. (2010) Deutschland schafft sich ab, München: Deutsche Verlags-Anstalt.

Statistisches Bundesamt (2012) Geburten in Deutschland, Wiesbaden.

Stevens, G. (1985) Nativity, Intermarriage, and Mother-Tongue Shift. American Sociological Review, 50 (1), 74-83.

Stichnoth, H. and Yester, M. (2013) Cultural Influences on the Fertility Behaviour of First and Second Generation Immigrants in Germany, ZEW Discussion Paper No. 13-023, Mannheim.

Sweetman, A. and van Ours, J. (2014) Immigration: What about the Children and Grandchildren?, IZA Discussion Paper No. 7919.

Toulement, L. (2004) La fecondité des immigrées: nouvelles données, nouvelle approche, Population et Sociétés, no. 400, Institut National d'Etudes Démographiques (INED), Paris.

Van Ours, J. C. and Veenman, J. (2003) The Educational Attainment of Second-Generation Immigrants in the Netherlands. Journal of Population Economics, 16 (4), 739-753. 
Wagner, G. G., Frick, J. R., \& Schupp, J. (2007): The German Socio-Economic Panel study (SOEP)-evolution, scope and enhancements, Schmollers Jahrbuch 127 (1), 139-169.

Yun, M.-S. (2004) Decomposing differences in the first moment, Economics Letters, 82 (2), 275280. 


\section{Tables}

Table 1 Share of High Education Track Attendance by Immigrant Generation and Source Country Group

\begin{tabular}{|c|c|c|c|c|}
\hline & \multicolumn{2}{|c|}{$\begin{array}{l}\text { Share of people on the } \\
\text { high education track } \\
\text { (in \%) }\end{array}$} & \multicolumn{2}{|c|}{ Number of observations } \\
\hline & France & Germany & France & Germany \\
\hline Natives & 59.7 & 47.3 & 11,510 & 37,514 \\
\hline First-generation immigrants & 43.6 & 36.7 & 456 & 3,924 \\
\hline Second-generation immigrants & 55.6 & 42.4 & 2,211 & 5,658 \\
\hline Immigrants from Western Europe & 53.3 & 40.9 & 835 & 1,474 \\
\hline Immigrants from Eastern Europe & 63.9 & 41.6 & 141 & 1,723 \\
\hline Immigrants from Turkey (Fr: or Middle East) & 35.8 & 31.7 & 145 & 2,015 \\
\hline Immigrants from Africa (Ger: or Middle East) & 50.7 & 42.9 & 1,507 & 511 \\
\hline Ethnic Germans & - & 40.0 & - & 2,855 \\
\hline
\end{tabular}

Source: French Labor Force Survey (Enquête de l'Emploi) and German Microcensus (2005 and 2008) and GSOEP, author calculations. 
Table 2: Results of the Blinder-Oaxaca Decomposition (Dependent Variable: High Education Track Attendance)

\begin{tabular}{|c|c|c|c|c|c|c|}
\hline & & \multicolumn{5}{|c|}{ France } \\
\hline & $\begin{array}{l}\text { First generation } \\
\text { immigrants }\end{array}$ & $\begin{array}{l}\text { Second generation } \\
\text { immigrants }\end{array}$ & $\begin{array}{l}\text { Immigrants from } \\
\text { Western Europe }\end{array}$ & $\begin{array}{l}\text { Immigrants from } \\
\text { Eastern Europe }\end{array}$ & $\begin{array}{l}\text { Immigrants from } \\
\text { Turkey / Middle East }\end{array}$ & $\begin{array}{l}\text { Immigrants from } \\
\text { Africa }\end{array}$ \\
\hline & Coeff. & Coeff. & Coeff. & Coeff. & Coeff. & Coeff. \\
\hline High education track (natives) & 59.7 & 59.7 & 59.7 & 59.7 & 59.7 & 59.7 \\
\hline High education track (immigrants) & 43.6 & 55.6 & 53.3 & 63.9 & 35.8 & 50.7 \\
\hline Gap (Difference natives-immigrants) & 16.1 & 4.1 & 6.4 & -4.2 & 23.9 & 9.0 \\
\hline Gap explained & 10.8 & 12.1 & 7.2 & -3.9 & 20.8 & 16.9 \\
\hline \multicolumn{7}{|l|}{ Contributions from differences in } \\
\hline \multirow[t]{2}{*}{ Number of siblings } & $2.3 * * *$ & $2.2 * * *$ & 0.1 & -0.1 & $3.0 * * *$ & $3.3^{* * *}$ \\
\hline & $(0.5)$ & $(0.4)$ & $(0.2)$ & $(0.4)$ & $(0.7)$ & $(0.5)$ \\
\hline \multirow[t]{2}{*}{ Parents' educational background } & $6.0 * * *$ & $7.9 * * *$ & $6.4^{* * *}$ & $-5.8 * * *$ & $13.6 * * *$ & $10.5 * * *$ \\
\hline & $(1.3)$ & $(0.7)$ & $(0.8)$ & $(2.0)$ & $(1.6)$ & $(0.8)$ \\
\hline \multirow[t]{2}{*}{ Parents' income } & $2.9 * * *$ & $2.0 * * *$ & $0.8^{* * *}$ & $1.4^{* * *}$ & $3.9 * * *$ & $3.1 * * *$ \\
\hline & $(0.5)$ & $(0.3)$ & $(0.2)$ & $(0.5)$ & $(0.7)$ & $(0.4)$ \\
\hline \multirow[t]{2}{*}{ Age and gender } & -0.5 & 0.0 & -0.2 & 0.2 & -0.1 & -0.2 \\
\hline & $(0.4)$ & $(0.2)$ & $(0.3)$ & $(0.7)$ & $(0.6)$ & $(0.2)$ \\
\hline \multirow[t]{2}{*}{ Year dummy variables } & 0.2 & 0.1 & 0.0 & 0.3 & 0.4 & 0.1 \\
\hline & $(0.1)$ & $(0.1)$ & $(0.1)$ & $(0.2)$ & $(0.2)$ & $(0.1)$ \\
\hline
\end{tabular}


Table 2: Results of the Blinder-Oaxaca Decomposition (Dependent Variable: High Education Track Attendance) - continued

\begin{tabular}{|c|c|c|c|c|c|c|c|}
\hline & \multicolumn{7}{|c|}{ Germany } \\
\hline & $\begin{array}{l}\text { First generation } \\
\text { immigrants }\end{array}$ & $\begin{array}{l}\text { Second generation } \\
\text { immigrants }\end{array}$ & $\begin{array}{l}\text { Immigrants from } \\
\text { Western Europe }\end{array}$ & $\begin{array}{l}\text { Immigrants from } \\
\text { Eastern Europe }\end{array}$ & $\begin{array}{c}\text { Immigrants from } \\
\text { Turkey }\end{array}$ & $\begin{array}{l}\text { Immigrants from } \\
\text { Africa / Middle East }\end{array}$ & Ethnic Germans \\
\hline & Coeff. & Coeff. & Coeff. & Coeff. & Coeff. & Coeff. & Coeff. \\
\hline High education track (natives) & 47.2 & 47.2 & 47.2 & 47.2 & 47.2 & 47.2 & 47.2 \\
\hline High education track (immigrants) & 35.7 & 42.3 & 40.9 & 41.2 & 31.6 & 42.5 & 39.6 \\
\hline Gap (Difference natives-immigrants) & 11.5 & 4.9 & 6.3 & 6.0 & 15.6 & 4.7 & 7.6 \\
\hline Gap explained & 5.1 & 9.7 & 6.6 & 1.8 & 25.4 & 8.3 & 1.5 \\
\hline \multicolumn{8}{|l|}{ Contributions from differences in } \\
\hline \multirow[t]{2}{*}{ Number of siblings } & $1.1 * * *$ & $1.2 * * *$ & $0.8 * * *$ & $0.3 *$ & $2.7 * * *$ & $3.1 * * *$ & $0.3 * *$ \\
\hline & $(0.2)$ & $(0.2)$ & $(0.2)$ & $(0.2)$ & $(0.4)$ & $(0.5)$ & $(0.1)$ \\
\hline \multirow[t]{2}{*}{ Parents' educational background } & $3.1 * * *$ & $8.1 * * *$ & $6.0 * * *$ & 0.2 & $21.7 * * *$ & 3.0 & 1.1 \\
\hline & $(0.8)$ & $(0.8)$ & $(1.5)$ & (1.1) & $(1.4)$ & (2.2) & $(0.7)$ \\
\hline \multirow[t]{2}{*}{ Parents' income } & $0.9 * * *$ & $0.3 * *$ & 0.0 & $0.8 * * *$ & $0.7 * * *$ & $1.1 * * *$ & $0.5 * * *$ \\
\hline & $(0.2)$ & $(0.1)$ & $(0.1)$ & $(0.2)$ & $(0.2)$ & $(0.3)$ & $(0.1)$ \\
\hline \multirow[t]{2}{*}{ Age and gender } & 0.1 & -0.2 & -0.5 & 0.2 & 0.0 & $0.8 * *$ & -0.2 \\
\hline & $(0.1)$ & $(0.1)$ & $(0.3)$ & $(0.2)$ & $(0.2)$ & $(0.4)$ & $(0.1)$ \\
\hline \multirow[t]{2}{*}{ Year dummy variables } & -0.1 & $0.4 * * *$ & 0.2 & $0.2 *$ & $0.4 * * *$ & $0.4^{* *}$ & -0.2 \\
\hline & $(0.1)$ & $(0.1)$ & $(0.2)$ & $(0.1)$ & $(0.1)$ & $(0.2)$ & $(0.1)$ \\
\hline
\end{tabular}

Notes: These are the results of a Blinder-Oaxaca Decomposition. Characteristics evaluated at native coefficients. The French sample is restricted to students aged 16-20, in the German sample students are aged 17-20. The outcome variable is "high education track attendance". Reported standard errors are robust and clustered by household. * denotes statistical significance at the $10 \%$ level, ** at the $5 \%$ level and *** at the $1 \%$ level.

Source: French Labor Force Survey (Enquête de l'Emploi) and German Microcensus (2005 and 2008) and GSOEP, author calculations. 
Table 3 Regression Results by Immigrant Generation (Dependent Variable: High Education Track Attendance)

\begin{tabular}{|c|c|c|c|c|c|c|}
\hline & \multicolumn{3}{|c|}{ France } & \multicolumn{3}{|c|}{ Germany } \\
\hline & Natives & $\begin{array}{c}\text { First } \\
\text { generation }\end{array}$ & $\begin{array}{c}\text { Second } \\
\text { generation }\end{array}$ & Natives & $\begin{array}{c}\text { First } \\
\text { generation }\end{array}$ & $\begin{array}{c}\text { Second } \\
\text { generation }\end{array}$ \\
\hline \multicolumn{7}{|l|}{ Number of siblings: (Reference: 1 sibling) } \\
\hline 0 siblings & $\begin{array}{l}0.021^{*} \\
(0.013)\end{array}$ & $\begin{array}{l}-0.093 \\
(0.088)\end{array}$ & $\begin{array}{c}0.013 \\
(0.034)\end{array}$ & $\begin{array}{c}-0.001 \\
(0.009)\end{array}$ & $\begin{array}{l}-0.009 \\
(0.028)\end{array}$ & $\begin{array}{c}0.034 \\
(0.025)\end{array}$ \\
\hline 2 siblings & $\begin{array}{l}-0.023^{*} \\
(0.013)\end{array}$ & $\begin{array}{l}-0.079 \\
(0.079)\end{array}$ & $\begin{array}{l}0.050^{*} \\
(0.030)\end{array}$ & $\begin{array}{c}-0.048 * * * \\
(0.011)\end{array}$ & $\begin{array}{l}-0.028 \\
(0.036)\end{array}$ & $\begin{array}{l}-0.024 \\
(0.027)\end{array}$ \\
\hline 3 or more siblings & $\begin{array}{c}-0.099 * * * \\
(0.017)\end{array}$ & $\begin{array}{c}-0.182^{* *} \\
(0.071)\end{array}$ & $\begin{array}{l}-0.077^{* *} \\
(0.032)\end{array}$ & $\begin{array}{c}-0.108^{* * *} \\
(0.015)\end{array}$ & $\begin{array}{c}-0.079^{* *} \\
(0.039)\end{array}$ & $\begin{array}{l}-0.020 \\
(0.028)\end{array}$ \\
\hline Female & $\begin{array}{c}0.134^{* * *} \\
(0.010)\end{array}$ & $\begin{array}{c}0.171^{* * *} \\
(0.053)\end{array}$ & $\begin{array}{l}0.179 * * * \\
(0.022)\end{array}$ & $\begin{array}{c}0.104^{* * *} \\
(0.007)\end{array}$ & $\begin{array}{c}0.092 * * * \\
(0.024)\end{array}$ & $\begin{array}{l}0.053^{* * *} \\
(0.019)\end{array}$ \\
\hline Age & $\begin{array}{c}0.005 \\
(0.003)\end{array}$ & $\begin{array}{c}0.016 \\
(0.018)\end{array}$ & $\begin{array}{l}0.023^{* * *} \\
(0.008)\end{array}$ & $\begin{array}{c}0.001 \\
(0.002)\end{array}$ & $\begin{array}{l}-0.004 \\
(0.007)\end{array}$ & $\begin{array}{c}0.008 \\
(0.006)\end{array}$ \\
\hline \multicolumn{7}{|l|}{ Mother's education: (Reference: medium education) } \\
\hline Mother lower education & $\begin{array}{c}-0.074^{* * *} \\
(0.015)\end{array}$ & $\begin{array}{l}-0.033 \\
(0.109)\end{array}$ & $\begin{array}{l}-0.051 \\
(0.038)\end{array}$ & $\begin{array}{c}-0.168^{* * *} \\
(0.015)\end{array}$ & $\begin{array}{l}-0.039 \\
(0.029)\end{array}$ & $\begin{array}{l}-0.087^{* * *} \\
(0.028)\end{array}$ \\
\hline Mother higher education & $\begin{array}{c}0.233^{* * *} \\
(0.015)\end{array}$ & $\begin{array}{c}0.082 \\
(0.117)\end{array}$ & $\begin{array}{l}0.194 * * * \\
(0.041)\end{array}$ & $\begin{array}{c}0.228 * * * \\
(0.011)\end{array}$ & $\begin{array}{c}0.208^{* * *} \\
(0.044)\end{array}$ & $\begin{array}{l}0.239 * * * \\
(0.028)\end{array}$ \\
\hline No information on educational status & & & & $\begin{array}{c}-0.033^{* *} \\
(0.016)\end{array}$ & $\begin{array}{l}-0.094^{*} \\
(0.051)\end{array}$ & $\begin{array}{l}-0.002 \\
(0.059)\end{array}$ \\
\hline \multicolumn{7}{|l|}{ Father's education: (Reference: medium education) } \\
\hline Father lower education & $\begin{array}{c}-0.044^{* * *} \\
(0.015)\end{array}$ & $\begin{array}{l}-0.163 \\
(0.101)\end{array}$ & $\begin{array}{l}-0.024 \\
(0.039)\end{array}$ & $\begin{array}{c}-0.081^{* * *} \\
(0.026)\end{array}$ & $\begin{array}{l}-0.040 \\
(0.032)\end{array}$ & $\begin{array}{l}-0.036 \\
(0.029)\end{array}$ \\
\hline Father higher education & $\begin{array}{c}0.169 * * * \\
(0.015)\end{array}$ & $\begin{array}{c}0.041 \\
(0.113)\end{array}$ & $\begin{array}{l}0.124^{* * *} \\
(0.042)\end{array}$ & $\begin{array}{c}0.269 * * * \\
(0.011)\end{array}$ & $\begin{array}{c}0.161^{* * *} \\
(0.048)\end{array}$ & $\begin{array}{l}0.196 * * * \\
(0.029)\end{array}$ \\
\hline No information on father's educational status & $\begin{array}{l}-0.000 \\
(0.016)\end{array}$ & $\begin{array}{l}-0.074 \\
(0.114)\end{array}$ & $\begin{array}{l}-0.073^{*} \\
(0.043)\end{array}$ & $\begin{array}{c}0.030 * * * \\
(0.010)\end{array}$ & $\begin{array}{l}-0.020 \\
(0.030)\end{array}$ & $\begin{array}{l}-0.032 \\
(0.030)\end{array}$ \\
\hline \multicolumn{7}{|c|}{ Monthly household income: (Reference: $€ 1500-€ 3200$ ) } \\
\hline Monthly household income $(<€ 1500)$ & $\begin{array}{c}-0.068^{* * *} \\
(0.014)\end{array}$ & $\begin{array}{c}0.012 \\
(0.081)\end{array}$ & $\begin{array}{l}-0.058^{*} \\
(0.031)\end{array}$ & $\begin{array}{c}-0.052^{* * *} \\
(0.015)\end{array}$ & $\begin{array}{l}-0.053^{*} \\
(0.028)\end{array}$ & $\begin{array}{l}-0.009 \\
(0.032)\end{array}$ \\
\hline Monthly household income (€ $3200-€ 7500)$ & $\begin{array}{c}0.046 * * * \\
(0.014)\end{array}$ & $\begin{array}{c}0.090 \\
(0.102)\end{array}$ & $\begin{array}{c}0.032 \\
(0.038)\end{array}$ & $\begin{array}{c}0.010 \\
(0.008)\end{array}$ & $\begin{array}{l}-0.009 \\
(0.023)\end{array}$ & $\begin{array}{c}0.000 \\
(0.020)\end{array}$ \\
\hline Monthly household income $(>=€ 7500)$ & $\begin{array}{c}0.034 \\
(0.026)\end{array}$ & $\begin{array}{l}-0.075 \\
(0.263)\end{array}$ & $\begin{array}{c}0.085 \\
(0.063)\end{array}$ & $\begin{array}{c}0.088 * * * \\
(0.017)\end{array}$ & $\begin{array}{c}0.194 * * * \\
(0.074)\end{array}$ & $\begin{array}{l}0.093^{*} \\
(0.048)\end{array}$ \\
\hline No information on monthly household income & $\begin{array}{c}-0.058^{* * *} \\
(0.015)\end{array}$ & $\begin{array}{c}0.013 \\
(0.080)\end{array}$ & $\begin{array}{l}-0.052 \\
(0.031)\end{array}$ & $\begin{array}{c}0.035^{* *} \\
(0.014)\end{array}$ & $\begin{array}{l}-0.017 \\
(0.038)\end{array}$ & $\begin{array}{c}0.028 \\
(0.032)\end{array}$ \\
\hline Year fixed-effects & yes & yes & yes & yes & yes & yes \\
\hline Constant & $\begin{array}{c}0.386 * * * \\
(0.065)\end{array}$ & $\begin{array}{c}0.290 \\
(0.348)\end{array}$ & $\begin{array}{c}0.066 \\
(0.151)\end{array}$ & $\begin{array}{c}0.306 * * * \\
(0.044)\end{array}$ & $\begin{array}{l}0.253^{*} \\
(0.130)\end{array}$ & $\begin{array}{c}0.094 \\
(0.109)\end{array}$ \\
\hline R-squared & 0.198 & 0.117 & 0.138 & 0.172 & 0.120 & 0.151 \\
\hline $\mathrm{N}$ & 11,510 & 456 & 2,211 & 37,514 & 3,924 & 5,658 \\
\hline
\end{tabular}

Notes: These are the coefficients of a linear probability model. The French sample is restricted to students aged 1620, in the German sample students are aged 17-20. The outcome variable is "high education track attendance". Reported standard errors are robust and clustered by household. * denotes statistical significance at the $10 \%$ level, $* *$ at the $5 \%$ level and *** at the $1 \%$ level.

Source: French Labor Force Survey (Enquête de l'Emploi) and German Microcensus (2005 and 2008) and GSOEP, author calculations. 


\section{Figures}

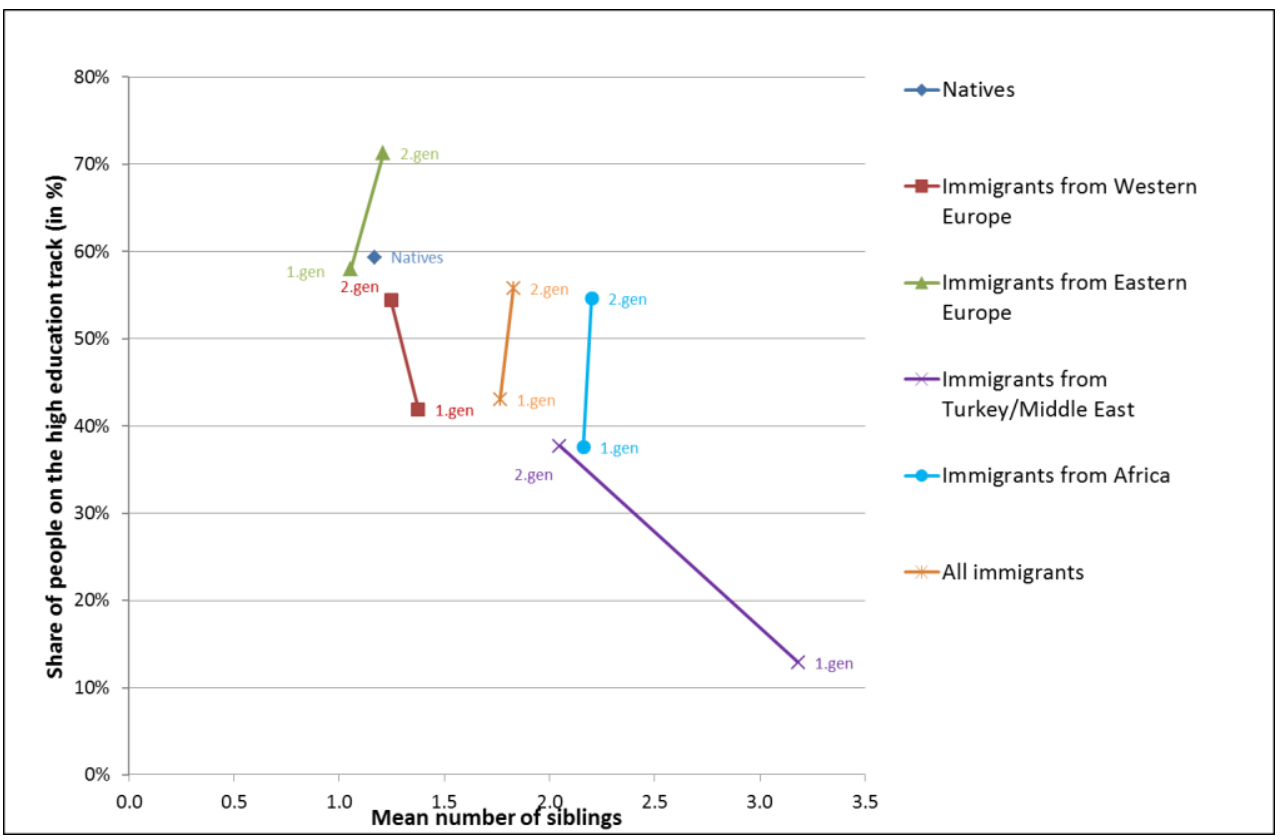

Fig. 1a Number of Siblings and Higher Track Attendance by Immigrant Generation and Source Country Group: France

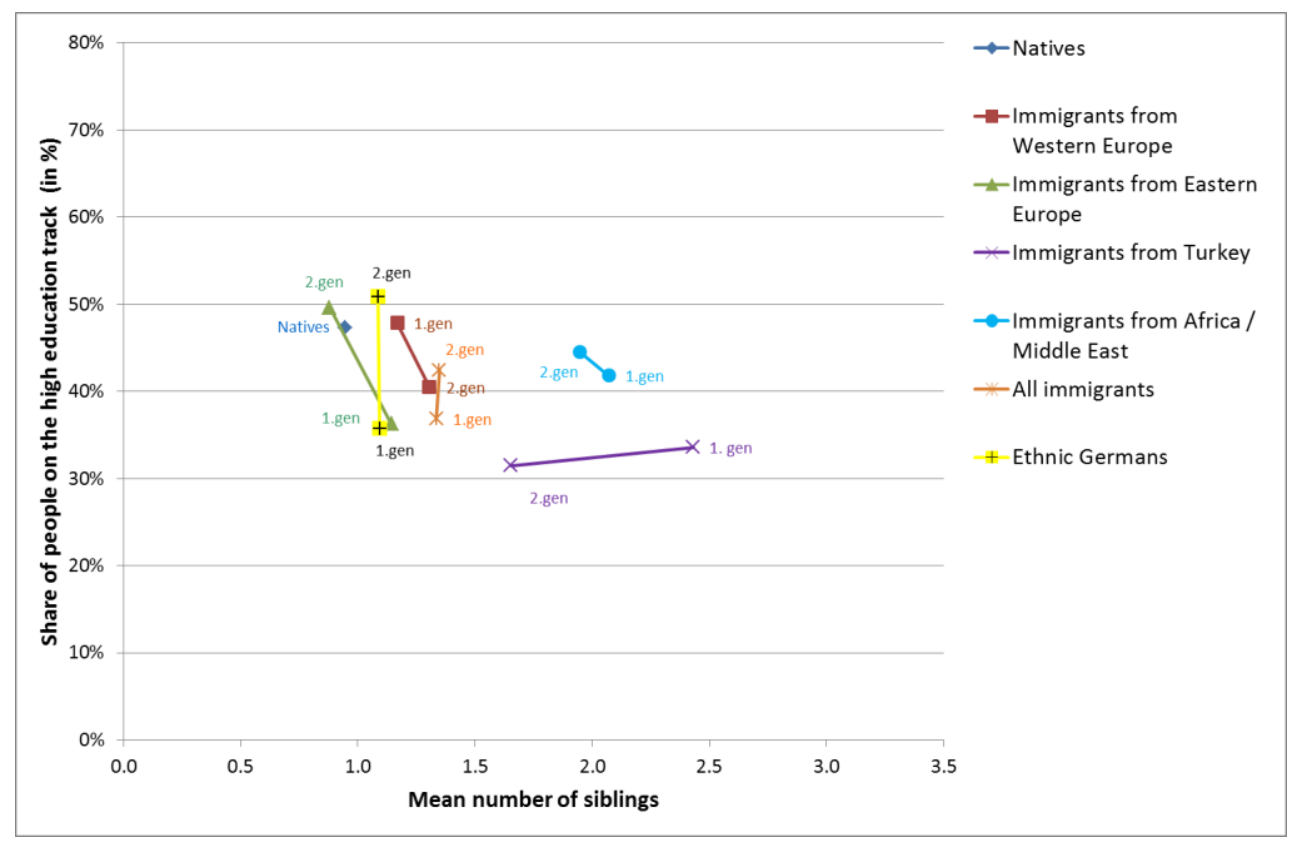

Fig. 1b Number of Siblings and Higher Track Attendance by Immigrant Generation and Source Country Group: Germany 


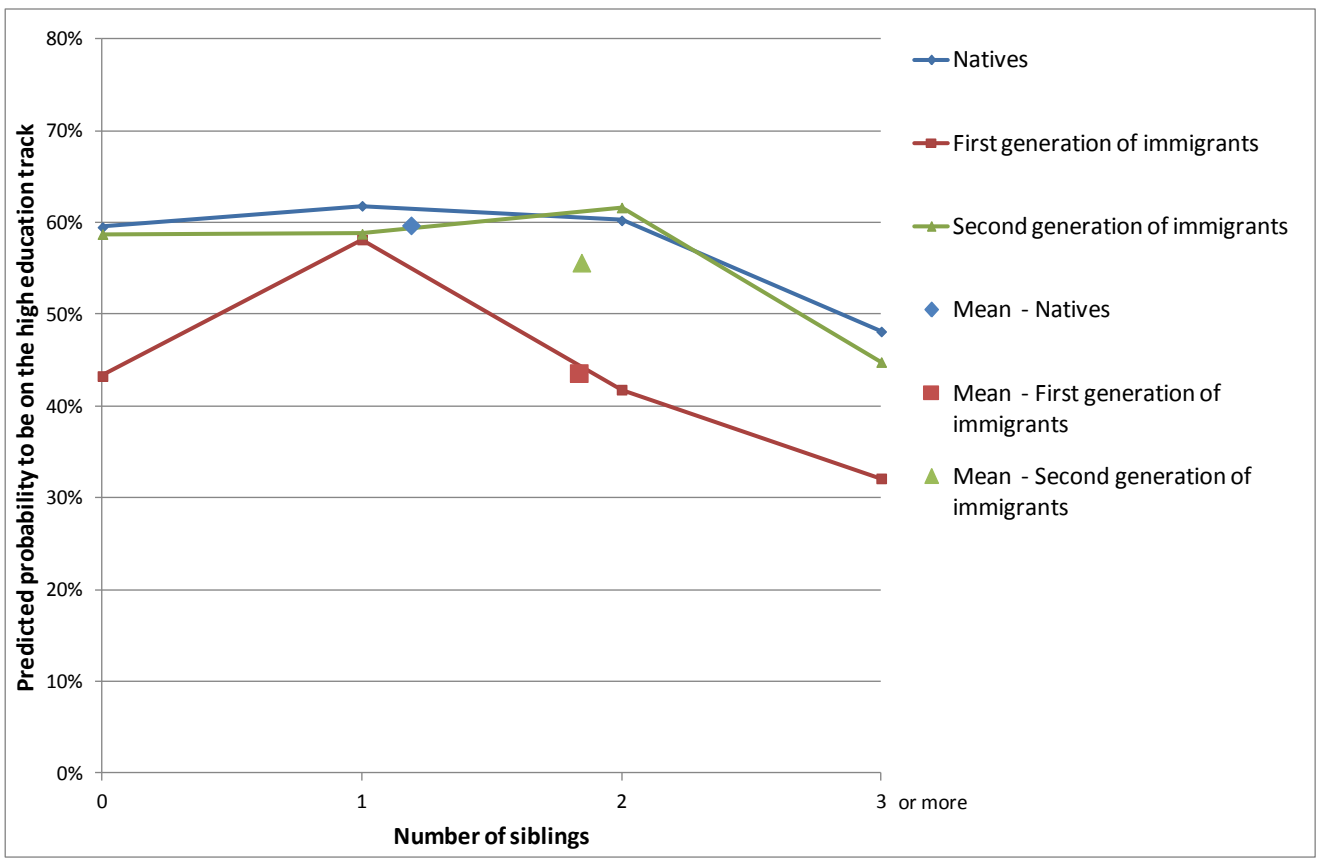

Fig. 2a Unconditional Higher Track Attendance by Immigrant Generation: France

Note: The standard error of the estimated probability of attending the higher education track ranges between 1 and 7 percentages points but mostly varies between 1 and 3 percentage points.

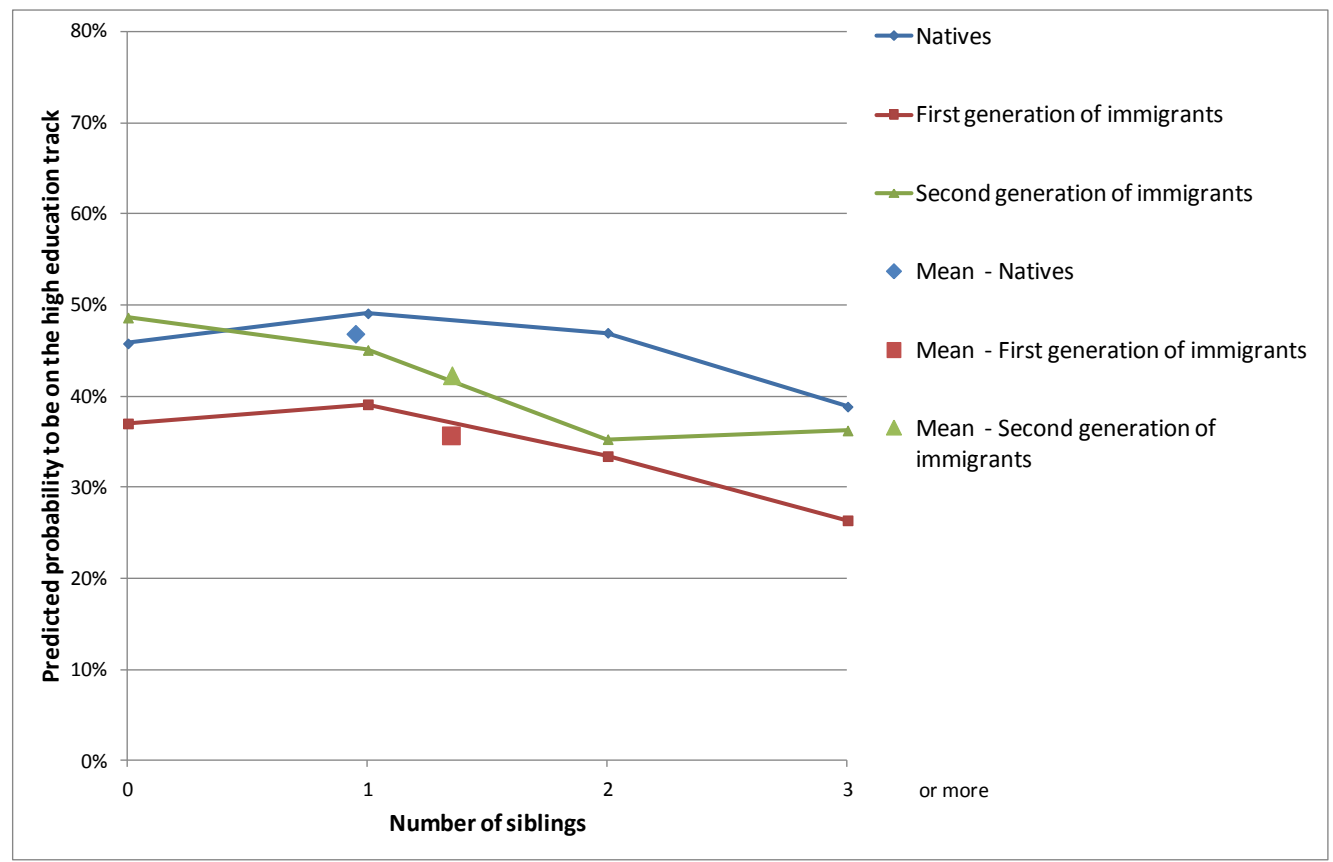

Fig. 2b Unconditional Higher Track Attendance by Immigrant Generation: Germany

Note: The standard error of the estimated probability of attending the higher education track ranges between 1 and 4 percentages points but mostly varies between 1 and 2 percentage points. 


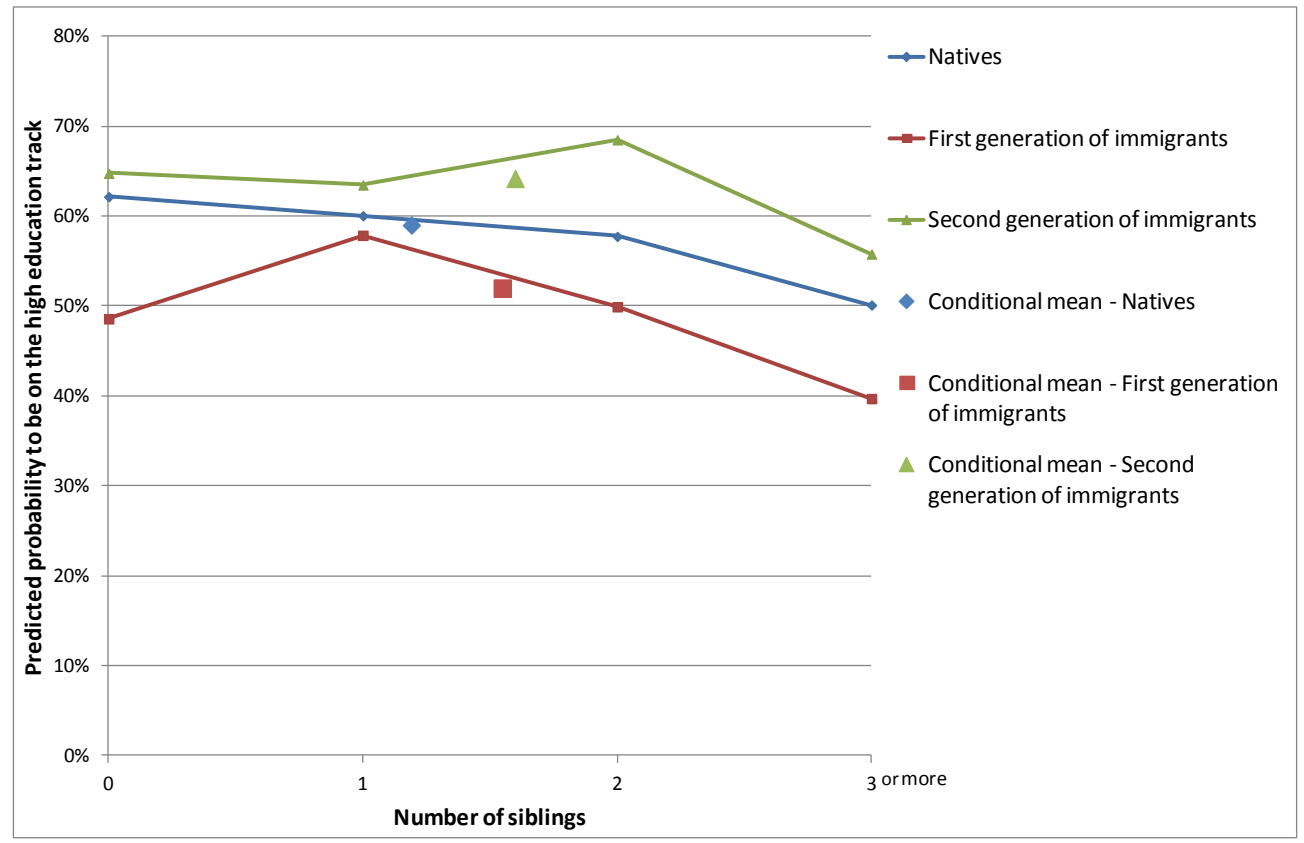

Fig. 3a Conditional Higher Track Attendance by Immigrant Generation: France

Note: The standard error of the estimated probability of attending the higher education track ranges between 1 and 9 percentages points but mostly varies between 1 and 3 percentage points.

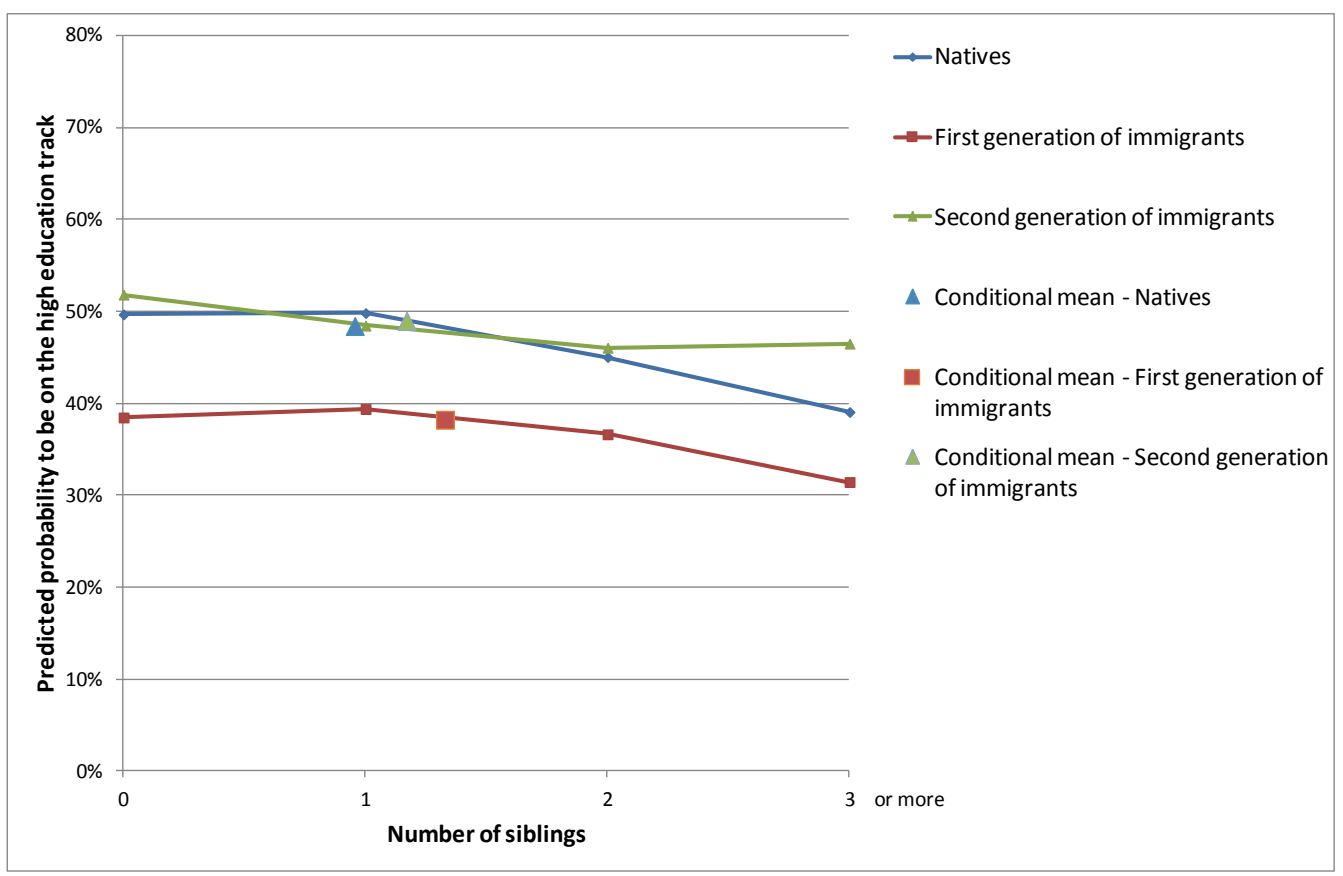

Fig. 3b Conditional Higher Track Attendance by Immigrant Generation: Germany

Note: The standard error of the estimated probability of attending the higher education track ranges between 1 and 5 percentages points but mostly varies between 1 and 3 percentage points. 


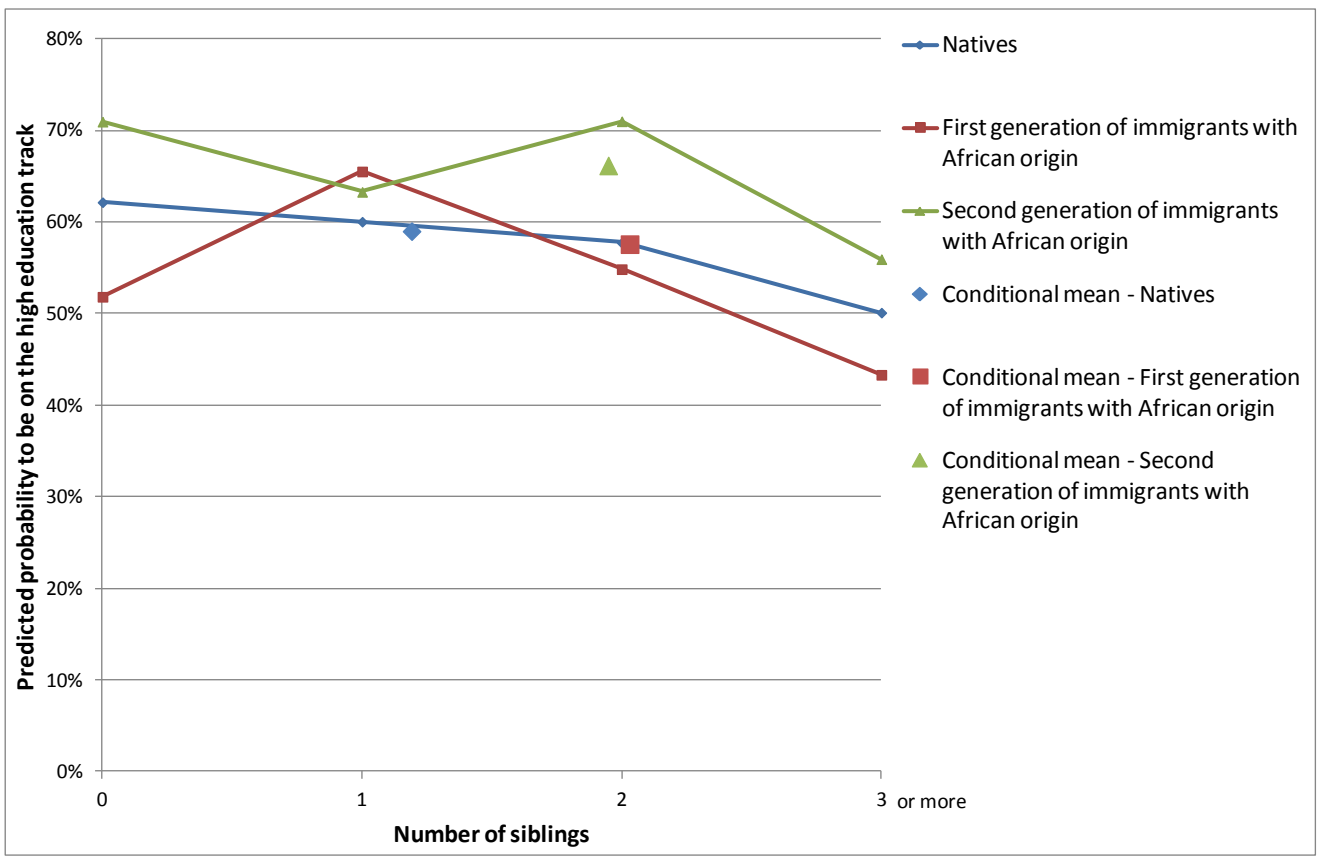

Fig. 4a Conditional Higher Track Attendance by Immigrant Generation: African Immigrants to France

Note: The standard error of the estimated probability of attending the higher education track ranges between 1 and 11 percentages points but mostly varies between 3 and 5 percentage points.

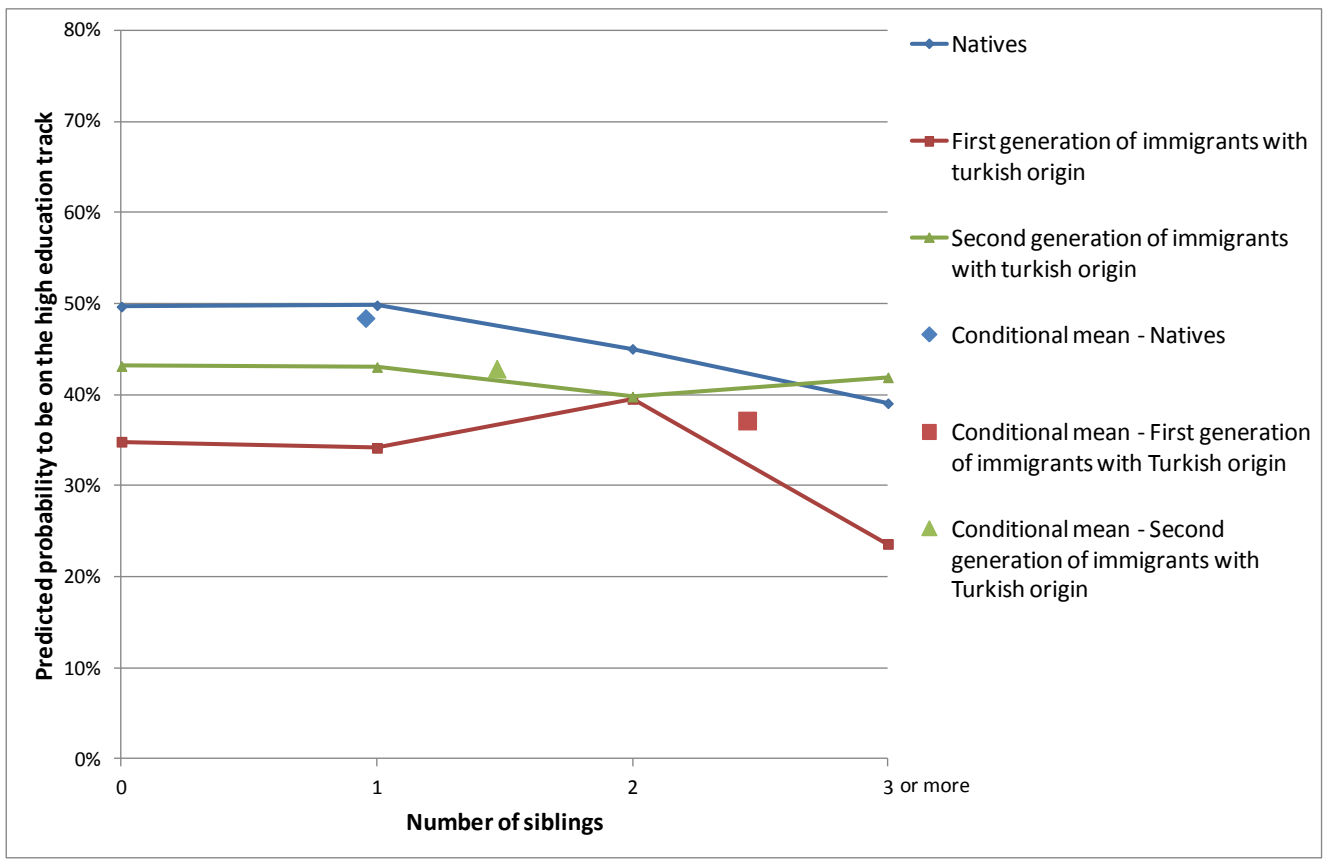

Fig. 4b Conditional Higher Track Attendance by Immigrant Generation: Turkish
Immigrants to Germany

Note: The standard error of the estimated probability of attending the higher education track ranges between 1 and 11 percentages points but mostly varies between 1 and 5 percentage points. 


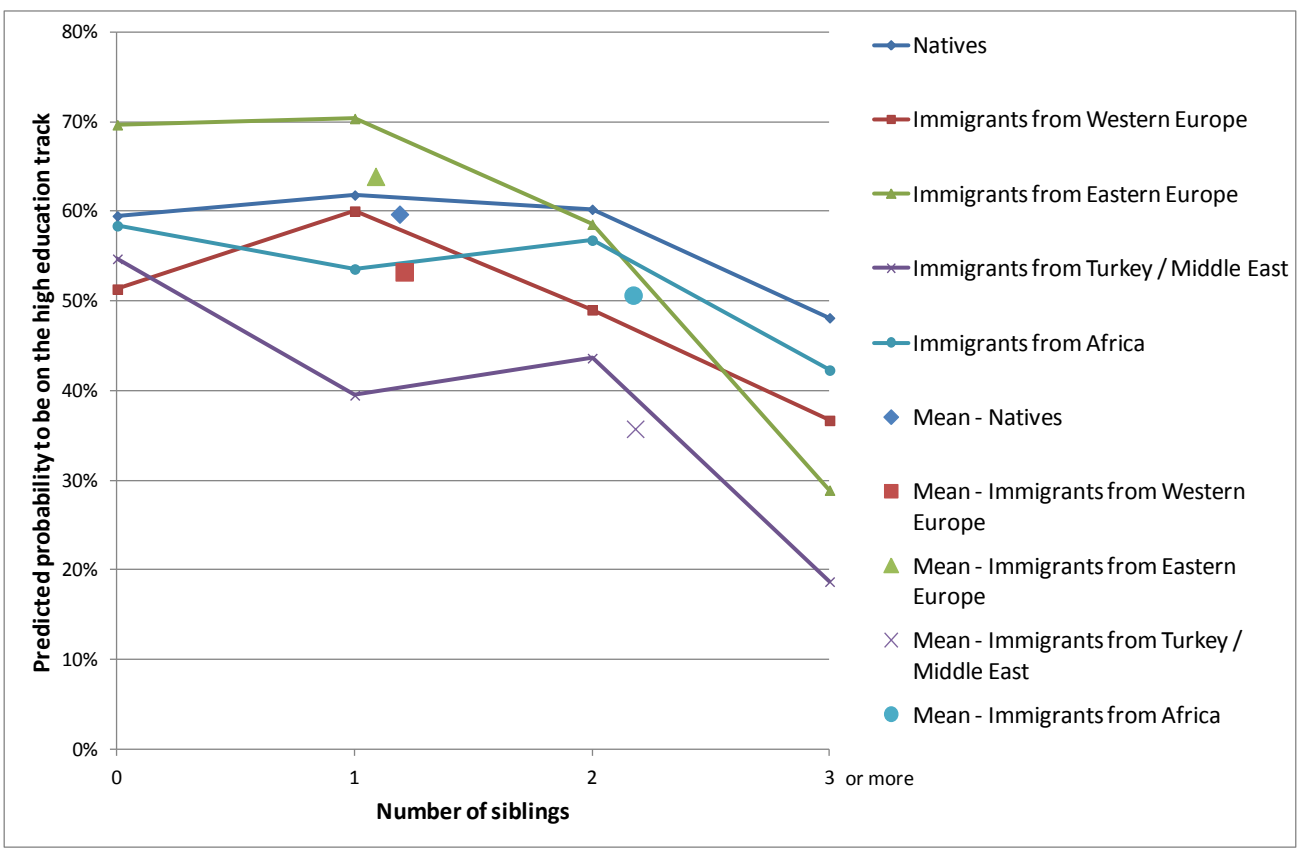

Fig. 5a Unconditional Higher Track Attendance by Source Country Group: France

Note: The standard error of the estimated probability of attending the higher education track ranges between 1 and 16 percentage points but mostly varies between 2 and 8 percentage points.

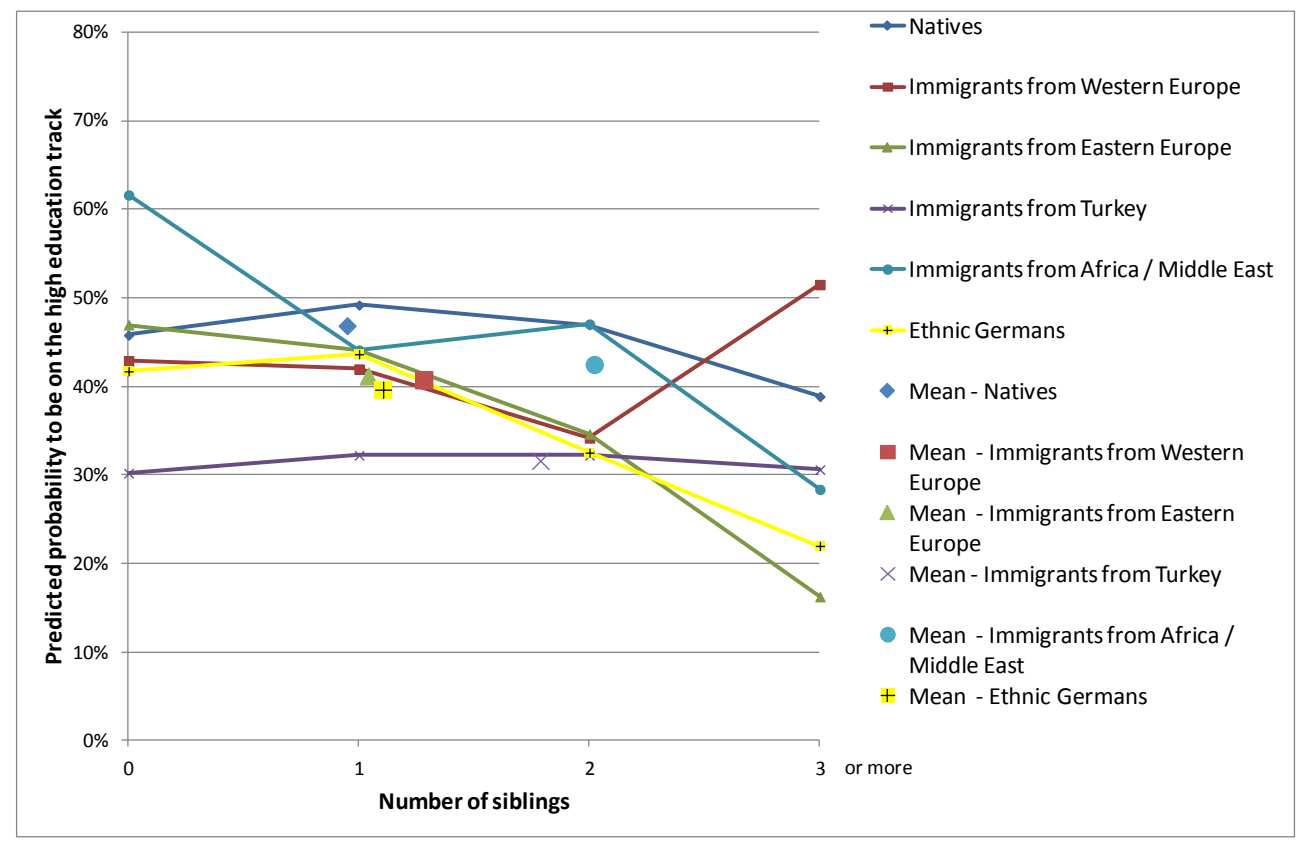

\section{Fig. 5b Unconditional Higher Track Attendance by Source Country Group: Germany}

Note: The standard error of the estimated probability of attending the higher education track ranges between 1 and 8 percentages points but mostly varies between 3 and 4 percentage points. 


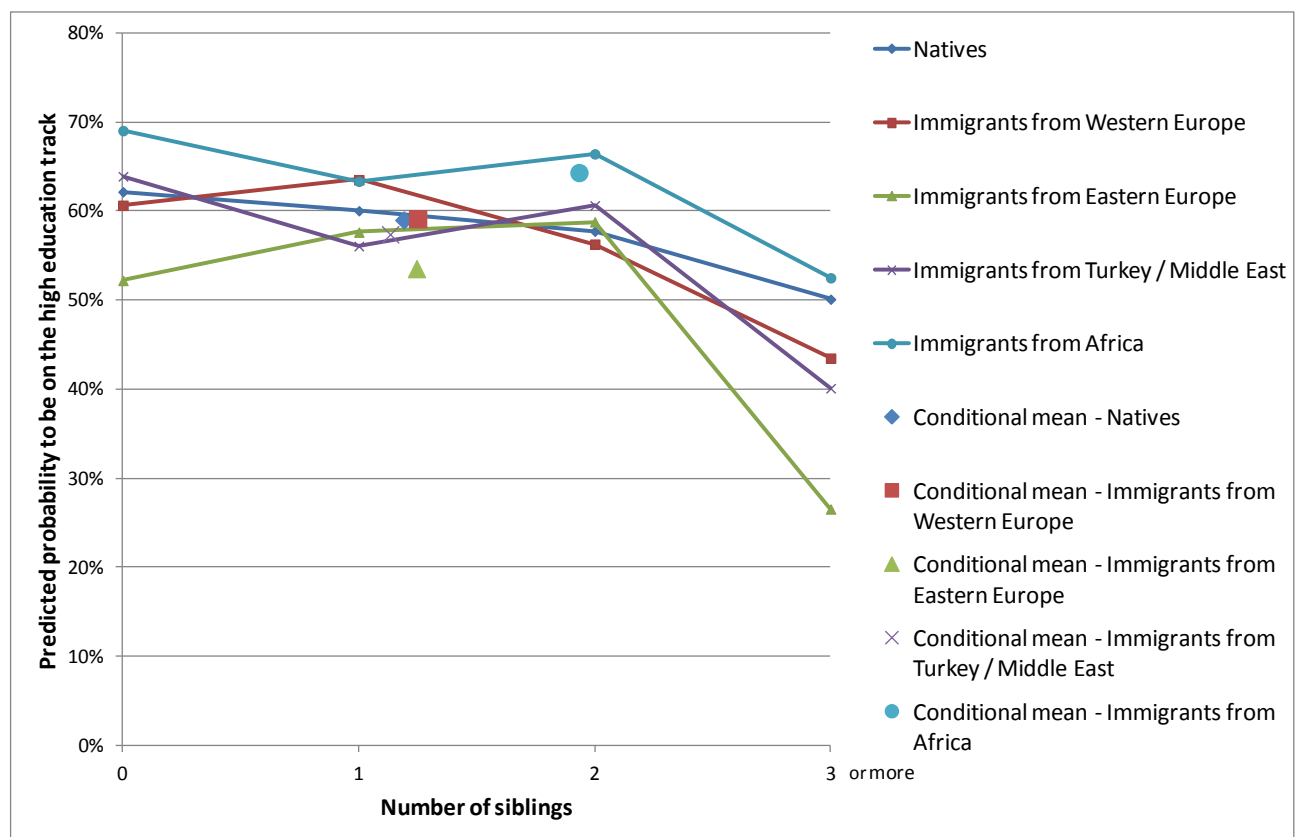

\section{Fig. 6a Conditional Higher Track Attendance by Source Country Group: France}

Note: The standard error of the estimated probability of attending the higher education track ranges between 1 and 12 percentages points but mostly varies between 3 and 8 percentage points.

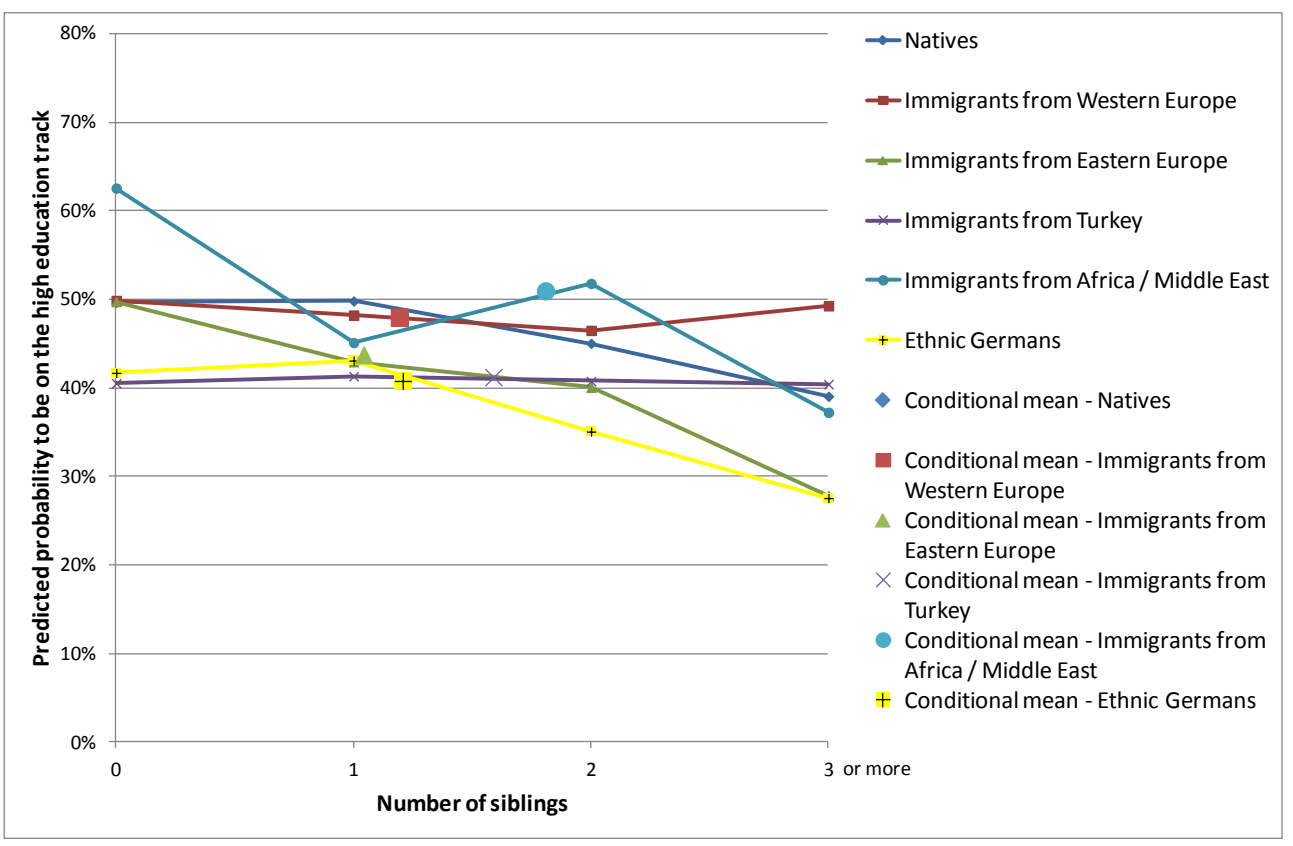

\section{Fig. 6b Conditional Higher Track Attendance by Source Country Group: Germany}

Note: The standard error of the estimated probability of attending the higher education track ranges between 1 and 9 percentages points but mostly varies between 3 and 5 percentage points. 


\section{Data Appendix}

\section{France}

The Enquête de l'Emploi consists of an individual data file and a household data file; however, only the latter contains information on children younger than 15 years. Information on parental education or origin has thus been obtained either from the children or directly from the parents by exploiting the household structure of the survey.

The Enquête de l'Emploi has a sample rotation system in which each selected household is interviewed in six consecutive quarters. The first, as well as the last, interviews are conducted face-to-face; the intermediate ones are carried out by telephone. In this paper, we pool data from 2006, 2007, 2008 and 2009 and because some variables used are only surveyed during the first interview, retain only the information from the first interview with each individual in the sample.

\section{Germany}

For Germany, we use data sets from the German Microcensus 2005 and 2008 and pooled data from the GSOEP for the years 2000 to 2009. The Microcensus, which covers $1 \%$ of all German households each year (researchers only obtain a "factually anonymous" $70 \%$ sub-sample of the Microcensus), is designed to provide representative information on the German population and labor market. In 2005, for the first time, additional questions were asked concerning migration.

In 2008, questions about parental nationality were only asked in the module that contributes to the EU Labor Force Survey, which is a random sample of $10 \%$ of the microcensus respondents. For the remaining children, information on parents' nationality could be obtained directly from the parents, again taking advantage of the survey's household structure. 
The German Socio Economic Panel (GSOEP), conducted since 1984, currently contains information on nearly 11,000 German households, including about 20,000 persons per year, and provides detailed information on socio-demographic characteristics. Once again, we were able to use the survey's household structure to obtain the parental characteristics of the children in our sample, which information we also used to identify first- and second-generation immigrants, as well as their origin.

\section{Definition of Origin}

A person's origin is defined according to his or her country of birth. If the individual is born in the host country or the country of birth is not specified, origin is defined based on citizenship/nationality. In the German Microcensus data, we can only distinguish those born in Germany from foreign-born persons. However, although information on the country of birth is unavailable, we know the person's current citizenship or citizenship before naturalization.

We distinguish the so-called "ethnic Germans" (mostly repatriates from Eastern Europe and the former Soviet Union) from immigrants from Eastern Europe because of their different status and characteristics. These ethnic German immigrants, former nationals of Poland, Romania, Russia, Slovakia, Czech Republic, Hungary, the Ukraine, Kazakhstan, Estonia, Lithuania, Latvia or other former Soviet republics or satellites, do not have to meet standard naturalization conditions and are naturalized shortly after arrival in Germany. We define immigrants from these countries naturalized within three years as ethnic Germans, a procedure that may also include spouses of ethnic Germans. Also included in this category are those not born in Germany and not indicated as naturalized but who hold German citizenship. Because of data limitations, it is not possible to apply this definition to the GSOEP data. However, using the 
variable "status upon migration to Germany", we can directly identify people who stated that they are ethnic Germans. 


\section{Appendix}

Table A1 Number of Observations by Immigrant Generation and Source Country Group

\begin{tabular}{|c|c|c|c|c|c|c|c|c|c|}
\hline $\begin{array}{l}\text { Immigrant } \\
\text { generation }\end{array}$ & Natives & $\begin{array}{l}\text { Immigrants from } \\
\text { Western Europe }\end{array}$ & $\begin{array}{l}\text { Immigrants from } \\
\text { Eastern Europe }\end{array}$ & $\begin{array}{l}\text { Immigrants from } \\
\text { Turkey (Fr: or } \\
\text { Middle East) }\end{array}$ & $\begin{array}{c}\text { Immigrants from } \\
\text { Africa (Ger: or } \\
\text { Middle East) }\end{array}$ & $\begin{array}{l}\text { Immigrants from } \\
\text { other countries }\end{array}$ & $\begin{array}{c}\text { Ethnic } \\
\text { Germans }\end{array}$ & Total & $\%$ \\
\hline \multicolumn{10}{|l|}{ France } \\
\hline Natives & 11,510 & 0 & 0 & 0 & 0 & 0 & - & 11,510 & 79.2 \\
\hline First-generation & 0 & 57 & 47 & 20 & 263 & 69 & - & 456 & 3.1 \\
\hline Second-generation & 0 & 585 & 56 & 124 & 1,130 & 316 & - & 2,211 & 15.2 \\
\hline Third-generation & 0 & 193 & 38 & 1 & 114 & 12 & - & 358 & 2.5 \\
\hline Total & 11,510 & 835 & 141 & 145 & 1,507 & 495 & - & 14,535 & - \\
\hline$\%$ & 79.2 & 5.7 & 1.0 & 1.0 & 10.4 & 3.4 & - & - & 100 \\
\hline \multicolumn{10}{|l|}{ Germany } \\
\hline Natives & 37,514 & 0 & 0 & 0 & 0 & 0 & 0 & 37,514 & 79.0 \\
\hline First-generation & 0 & 229 & 950 & 314 & 252 & 396 & 1,997 & 4,138 & 8.7 \\
\hline Second-generation & 0 & 1,216 & 766 & 1,689 & 258 & 873 & 856 & 5,658 & 11.9 \\
\hline Third-generation & 0 & 29 & 7 & 12 & 1 & 105 & 2 & 156 & 0.3 \\
\hline Total & 37,514 & 1,474 & 1,723 & 2,015 & 511 & 1,374 & 2,855 & 47,466 & - \\
\hline$\%$ & 79.0 & 3.1 & 3.6 & 4.2 & 1.1 & 2.9 & 6.0 & - & 100 \\
\hline
\end{tabular}

Source: French Labor Force Survey (Enquête de l'Emploi) and German Microcensus (2005 and 2008) and GSOEP, author calculations. 
Table A2 Sample Means - France

\begin{tabular}{|c|c|c|c|c|c|c|c|c|}
\hline \multirow{2}{*}{ Variable } & \multicolumn{2}{|c|}{ Total } & \multicolumn{2}{|c|}{ Natives } & \multicolumn{2}{|c|}{ First-generation } & \multicolumn{2}{|c|}{ Second-generation } \\
\hline & Mean & Std. Dev. & Mean & Std. Dev. & Mean & Std. Dev. & Mean & Std. Dev. \\
\hline High education track & 0.58 & 0.49 & 0.59 & 0.49 & 0.44 & 0.50 & 0.54 & 0.50 \\
\hline Number of siblings & 1.38 & 1.18 & 1.25 & 1.06 & 2.08 & 1.64 & 1.83 & 1.42 \\
\hline \multicolumn{9}{|l|}{ Dummy variables for number of siblings: } \\
\hline 0 siblings & 0.22 & 0.41 & 0.23 & 0.42 & 0.18 & 0.38 & 0.16 & 0.37 \\
\hline 1 sibling & 0.40 & 0.49 & 0.43 & 0.50 & 0.23 & 0.42 & 0.31 & 0.46 \\
\hline 2 siblings & 0.24 & 0.43 & 0.24 & 0.42 & 0.23 & 0.42 & 0.25 & 0.44 \\
\hline 3 or more siblings & 0.14 & 0.34 & 0.10 & 0.30 & 0.35 & 0.48 & 0.27 & 0.44 \\
\hline Female & 0.48 & 0.50 & 0.48 & 0.50 & 0.50 & 0.50 & 0.49 & 0.50 \\
\hline Age & 17.88 & 1.39 & 17.87 & 1.39 & 18.02 & 1.41 & 17.90 & 1.39 \\
\hline \multicolumn{9}{|l|}{ Origin: } \\
\hline Native & 0.79 & 0.41 & & & & & & \\
\hline Western Europe & 0.06 & 0.23 & & & 0.13 & 0.33 & 0.30 & 0.46 \\
\hline Eastern Europe & 0.01 & 0.10 & & & 0.10 & 0.30 & 0.04 & 0.19 \\
\hline Turkey/Middle East & 0.01 & 0.10 & & & 0.04 & 0.21 & 0.05 & 0.22 \\
\hline Africa & 0.10 & 0.30 & & & 0.58 & 0.49 & 0.48 & 0.50 \\
\hline Other countries & 0.03 & 0.16 & & & 0.15 & 0.36 & 0.13 & 0.33 \\
\hline \multicolumn{9}{|l|}{ Mother's education: } \\
\hline Lower education & 0.44 & 0.50 & 0.38 & 0.49 & 0.67 & 0.47 & 0.64 & 0.48 \\
\hline Medium education & 0.22 & 0.41 & 0.24 & 0.43 & 0.07 & 0.26 & 0.14 & 0.35 \\
\hline Higher education & 0.34 & 0.48 & 0.38 & 0.48 & 0.26 & 0.44 & 0.22 & 0.41 \\
\hline \multicolumn{9}{|l|}{ Father's education: } \\
\hline Lower education & 0.31 & 0.46 & 0.28 & 0.45 & 0.48 & 0.50 & 0.43 & 0.49 \\
\hline Medium education & 0.24 & 0.42 & 0.27 & 0.44 & 0.11 & 0.31 & 0.13 & 0.33 \\
\hline Higher education & 0.23 & 0.42 & 0.24 & 0.43 & 0.21 & 0.41 & 0.16 & 0.36 \\
\hline No information on educational status & 0.23 & 0.42 & 0.21 & 0.41 & 0.21 & 0.40 & 0.29 & 0.45 \\
\hline \multicolumn{9}{|c|}{ Dummy variables for monthly household income: } \\
\hline$<€ 1500$ & 0.24 & 0.42 & 0.22 & 0.41 & 0.34 & 0.47 & 0.31 & 0.46 \\
\hline$€ 1500-€ 3200$ & 0.35 & 0.48 & 0.36 & 0.48 & 0.21 & 0.41 & 0.30 & 0.46 \\
\hline$€ 3200-€ 7500$ & 0.21 & 0.41 & 0.25 & 0.43 & 0.08 & 0.27 & 0.10 & 0.30 \\
\hline$>=€ 7500$ & 0.02 & 0.12 & 0.02 & 0.13 & 0.00 & 0.07 & 0.01 & 0.09 \\
\hline No information on income & 0.19 & 0.39 & 0.16 & 0.36 & 0.37 & 0.48 & 0.29 & 0.45 \\
\hline \multicolumn{9}{|l|}{ Year dummy variables } \\
\hline 2006 & 0.22 & 0.42 & 0.23 & 0.42 & 0.20 & 0.40 & 0.20 & 0.40 \\
\hline 2007 & 0.23 & 0.42 & 0.23 & 0.42 & 0.21 & 0.41 & 0.23 & 0.42 \\
\hline 2008 & 0.22 & 0.41 & 0.22 & 0.41 & 0.23 & 0.42 & 0.22 & 0.42 \\
\hline 2009 & 0.33 & 0.47 & 0.32 & 0.47 & 0.36 & 0.48 & 0.34 & 0.47 \\
\hline Number of observations & \multicolumn{2}{|c|}{14,535} & \multicolumn{2}{|c|}{11,510} & \multicolumn{2}{|c|}{456} & \multicolumn{2}{|c|}{2,569} \\
\hline
\end{tabular}


Table A2 Sample Means - Germany - continued

\begin{tabular}{|c|c|c|c|c|c|c|c|c|}
\hline \multirow[b]{2}{*}{ Variable } & \multicolumn{2}{|c|}{ Total } & \multicolumn{2}{|c|}{ Natives } & \multicolumn{2}{|c|}{ First-generation } & \multicolumn{2}{|c|}{ Second-generation } \\
\hline & Mean & Std. Dev. & Mean & Std. Dev. & Mean & Std. Dev. & Mean & Std. Dev. \\
\hline High education track & 0.47 & 0.50 & 0.49 & 0.50 & 0.37 & 0.48 & 0.44 & 0.50 \\
\hline Number of siblings & 1.05 & 1.00 & 0.97 & 0.91 & 1.37 & 1.35 & 1.35 & 1.17 \\
\hline \multicolumn{9}{|l|}{ Dummy variables for number of siblings: } \\
\hline 0 siblings & 0.30 & 0.46 & 0.32 & 0.47 & 0.25 & 0.43 & 0.22 & 0.42 \\
\hline 1 sibling & 0.45 & 0.50 & 0.46 & 0.50 & 0.42 & 0.49 & 0.41 & 0.49 \\
\hline 2 siblings & 0.17 & 0.38 & 0.16 & 0.37 & 0.19 & 0.39 & 0.24 & 0.43 \\
\hline 3 or more siblings & 0.07 & 0.26 & 0.05 & 0.23 & 0.14 & 0.35 & 0.12 & 0.33 \\
\hline Female & 0.47 & 0.50 & 0.47 & 0.50 & 0.47 & 0.50 & 0.49 & 0.50 \\
\hline Age & 18.50 & 1.09 & 18.50 & 1.09 & 18.64 & 1.09 & 18.45 & 1.10 \\
\hline \multicolumn{9}{|l|}{ Origin: } \\
\hline Native & 0.79 & 0.41 & & & & & & \\
\hline Western Europe & 0.03 & 0.17 & & & 0.06 & 0.23 & 0.21 & 0.41 \\
\hline Eastern Europe & 0.04 & 0.19 & & & 0.23 & 0.42 & 0.13 & 0.34 \\
\hline Turkey & 0.04 & 0.20 & & & 0.08 & 0.26 & 0.29 & 0.45 \\
\hline Africa/Middle East & 0.01 & 0.10 & & & 0.06 & 0.24 & 0.04 & 0.21 \\
\hline Other countries & 0.03 & 0.17 & & & 0.10 & 0.29 & 0.17 & 0.37 \\
\hline Ethnic Germans & 0.06 & 0.24 & & & 0.48 & 0.50 & 0.15 & 0.35 \\
\hline \multicolumn{9}{|l|}{ Mother's education: } \\
\hline Lower education & 0.13 & 0.34 & 0.08 & 0.27 & 0.27 & 0.45 & 0.37 & 0.48 \\
\hline Medium education & 0.61 & 0.49 & 0.66 & 0.47 & 0.46 & 0.50 & 0.40 & 0.49 \\
\hline Higher education & 0.23 & 0.42 & 0.23 & 0.42 & 0.25 & 0.43 & 0.21 & 0.41 \\
\hline No information on educational status & 0.03 & 0.17 & 0.03 & 0.17 & 0.02 & 0.14 & 0.02 & 0.13 \\
\hline \multicolumn{9}{|l|}{ Father's education: } \\
\hline Lower education & 0.08 & 0.27 & 0.04 & 0.20 & 0.19 & 0.39 & 0.26 & 0.44 \\
\hline Medium education & 0.52 & 0.50 & 0.55 & 0.50 & 0.44 & 0.50 & 0.42 & 0.49 \\
\hline Higher education & 0.25 & 0.43 & 0.26 & 0.44 & 0.23 & 0.42 & 0.22 & 0.41 \\
\hline No information on educational status & 0.15 & 0.36 & 0.16 & 0.36 & 0.14 & 0.35 & 0.10 & 0.30 \\
\hline \multicolumn{9}{|c|}{ Dummy variables for monthly household income: } \\
\hline$<€ 1500$ & 0.09 & 0.29 & 0.08 & 0.28 & 0.16 & 0.37 & 0.09 & 0.29 \\
\hline$€ 1500-€ 3200$ & 0.42 & 0.49 & 0.40 & 0.49 & 0.54 & 0.50 & 0.50 & 0.50 \\
\hline$€ 3200-€ 7500$ & 0.36 & 0.48 & 0.38 & 0.49 & 0.22 & 0.41 & 0.30 & 0.46 \\
\hline$>=€ 7500$ & 0.03 & 0.17 & 0.03 & 0.18 & 0.01 & 0.11 & 0.02 & 0.15 \\
\hline No information on income & 0.08 & 0.27 & 0.08 & 0.27 & 0.06 & 0.24 & 0.08 & 0.27 \\
\hline \multicolumn{9}{|l|}{ Year dummy variables } \\
\hline 2000 & 0.03 & 0.17 & 0.03 & 0.16 & 0.03 & 0.17 & 0.03 & 0.18 \\
\hline 2001 & 0.03 & 0.16 & 0.03 & 0.16 & 0.03 & 0.16 & 0.03 & 0.16 \\
\hline 2002 & 0.03 & 0.16 & 0.03 & 0.16 & 0.03 & 0.16 & 0.02 & 0.15 \\
\hline 2003 & 0.03 & 0.16 & 0.03 & 0.16 & 0.02 & 0.15 & 0.02 & 0.15 \\
\hline 2004 & 0.02 & 0.16 & 0.03 & 0.16 & 0.02 & 0.15 & 0.02 & 0.15 \\
\hline 2005 & 0.37 & 0.48 & 0.37 & 0.48 & 0.41 & 0.49 & 0.32 & 0.47 \\
\hline 2006 & 0.02 & 0.16 & 0.03 & 0.16 & 0.02 & 0.13 & 0.03 & 0.16 \\
\hline 2007 & 0.02 & 0.15 & 0.02 & 0.16 & 0.01 & 0.12 & 0.03 & 0.16 \\
\hline 2008 & 0.43 & 0.50 & 0.43 & 0.49 & 0.43 & 0.49 & 0.48 & 0.50 \\
\hline 2009 & 0.02 & 0.13 & 0.02 & 0.14 & 0.01 & 0.08 & 0.02 & 0.15 \\
\hline Number of observations & & & & & & & & \\
\hline
\end{tabular}

Source: French Labor Force Survey (Enquête de l'Emploi) and German Microcensus (2005 and 2008) and GSOEP, author calculations. 
Table A3: $\quad$ Results of the Blinder-Oaxaca Decomposition (Dependent Variable: High Education Track Attendance), Evaluated at Immigrants' Coefficients

\begin{tabular}{|c|c|c|c|c|c|c|}
\hline & \multirow[b]{2}{*}{ First generation immigrants } & \multicolumn{4}{|c|}{ France } & \multirow[b]{2}{*}{$\begin{array}{l}\text { Immigrants from } \\
\text { Africa }\end{array}$} \\
\hline & & $\begin{array}{l}\text { Second generation } \\
\text { immigrants }\end{array}$ & $\begin{array}{l}\text { Immigrants from } \\
\text { Western Europe }\end{array}$ & $\begin{array}{l}\text { Immigrants from } \\
\text { Eastern Europe }\end{array}$ & $\begin{array}{l}\text { Immigrants from } \\
\text { Turkey / Middle East }\end{array}$ & \\
\hline & Coeff. & Coeff. & Coeff. & Coeff. & Coeff. & Coeff. \\
\hline High education track (natives) & 59.7 & 59.7 & 59.7 & 59.7 & 59.7 & 59.7 \\
\hline High education track (immigrants) & 43.6 & 55.6 & 53.3 & 63.9 & 35.8 & 50.7 \\
\hline Gap (difference natives-immigrants) & 16.1 & 4.1 & 6.4 & -4.2 & 23.9 & 9.0 \\
\hline Gap explained & 8.8 & 9.0 & 6.7 & -9.5 & 22.6 & 14.1 \\
\hline \multicolumn{7}{|l|}{ Contributions from differences in } \\
\hline \multirow[t]{2}{*}{ Number of siblings } & $3.5^{* *}$ & $1.4^{* *}$ & 0.1 & 1.0 & 4.5 & $3.9 * * *$ \\
\hline & $(1.4)$ & $(0.6)$ & $(0.3)$ & $(1.3)$ & $(3.2)$ & $(1.2)$ \\
\hline \multirow[t]{2}{*}{ Parents' educational background } & $4.9 * *$ & $6.0 * * *$ & $6.5^{* * *}$ & $-11.5^{* * *}$ & $11.9 *$ & $5.9 * * *$ \\
\hline & $(2.4)$ & $(1.0)$ & $(1.1)$ & $(3.7)$ & $(7.0)$ & $(1.8)$ \\
\hline \multirow[t]{2}{*}{ Parents' income } & 1.0 & $1.6^{* *}$ & 0.5 & 1.0 & 6.8 & $4.6^{* * *}$ \\
\hline & (2.1) & $(0.7)$ & $(0.5)$ & (1.8) & $(4.2)$ & $(1.7)$ \\
\hline \multirow[t]{2}{*}{ Age and gender } & -0.8 & 0.0 & -0.5 & 0.3 & -0.3 & -0.3 \\
\hline & $(0.6)$ & $(0.3)$ & $(0.5)$ & (1.1) & (1.3) & $(0.2)$ \\
\hline \multirow[t]{2}{*}{ Year dummy variables } & 0.3 & -0.1 & 0.0 & -0.4 & -0.3 & 0.0 \\
\hline & $(0.4)$ & $(0.1)$ & $(0.1)$ & $(0.7)$ & (1.1) & $(0.2)$ \\
\hline
\end{tabular}


Table A3: $\quad$ Results of the Blinder-Oaxaca Decomposition (Dependent Variable: High Education Track Attendance), Evaluated at Immigrants' Coefficients - continued

\begin{tabular}{|c|c|c|c|c|c|c|c|}
\hline & \multicolumn{7}{|c|}{ Germany } \\
\hline & First generation immigrants & $\begin{array}{l}\text { Second generation } \\
\text { immigrants }\end{array}$ & $\begin{array}{l}\text { Immigrants from } \\
\text { Western Europe }\end{array}$ & $\begin{array}{l}\text { Immigrants from } \\
\text { Eastern Europe }\end{array}$ & $\begin{array}{l}\text { Immigrants from } \\
\text { Turkey }\end{array}$ & $\begin{array}{l}\text { Immigrants from } \\
\text { Africa / Middle East }\end{array}$ & Ethnic Germans \\
\hline & Coeff. & Coeff. & Coeff. & Coeff. & Coeff. & Coeff. & Coeff. \\
\hline High education track (natives) & 47.2 & 47.2 & 47.2 & 47.2 & 47.2 & 47.2 & 47.2 \\
\hline High education track (immigrants) & 35.7 & 42.3 & 40.9 & 41.2 & 31.6 & 42.5 & 39.6 \\
\hline Gap (difference natives-immigrants) & 11.5 & 4.9 & 6.3 & 6.0 & 15.6 & 4.7 & 7.6 \\
\hline Gap explained & 1.5 & 5.6 & 5.6 & 1.4 & 9.2 & 8.3 & 0.1 \\
\hline \multicolumn{8}{|l|}{ Contributions from differences in } \\
\hline \multirow[t]{2}{*}{ Number of siblings } & $0.7 *$ & $0.7 *$ & 0.3 & 0.6 & 0.1 & $4.8^{* *}$ & $0.4 *$ \\
\hline & $(0.4)$ & $(0.4)$ & $(0.6)$ & $(0.4)$ & $(1.3)$ & $(2.2)$ & $(0.2)$ \\
\hline \multirow[t]{2}{*}{ Parents' educational background } & 0.2 & $4.1 * * *$ & $3.4 *$ & $-2.2 * *$ & $10.2 * * *$ & 0.2 & 0.4 \\
\hline & $(0.8)$ & $(0.9)$ & $(1.8)$ & (1.1) & $(2.9)$ & (3.3) & $(0.6)$ \\
\hline \multirow[t]{2}{*}{ Parents' income } & 0.7 & 0.1 & 0.2 & $2.4 * * *$ & $-1.5 *$ & 0.5 & 0.6 \\
\hline & $(0.5)$ & $(0.2)$ & $(0.4)$ & $(0.8)$ & $(0.8)$ & (1.7) & $(0.3)$ \\
\hline \multirow[t]{2}{*}{ Age and gender } & 0.1 & -0.1 & 0.0 & 0.1 & 0.0 & 0.8 & -0.1 \\
\hline & $(0.2)$ & $(0.1)$ & $(0.2)$ & $(0.1)$ & $(0.1)$ & $(0.5)$ & $(0.2)$ \\
\hline \multirow[t]{2}{*}{ Year dummy variables } & -0.2 & $0.7 * * *$ & $1.7^{* *}$ & 0.6 & 0.4 & $2.1 * *$ & $-1.0 * *$ \\
\hline & $(0.2)$ & $(0.2)$ & $(0.7)$ & $(0.4)$ & $(0.3)$ & $(1.0)$ & $(0.5)$ \\
\hline
\end{tabular}

Notes: These are the results of a Blinder-Oaxaca Decomposition. Characteristics evaluated at immigrant coefficients. The French sample is restricted to students aged 16-20, in the German sample students are aged 17-20. The outcome variable is "high education track attendance". Reported standard errors are robust and clustered by household. * denotes statistical significance at the $10 \%$ level, ** at the $5 \%$ level and *** at the $1 \%$ level.

Source: French Labor Force Survey (Enquête de l'Emploi) and German Microcensus (2005 and 2008) and GSOEP, author calculations. 
Table A4a Regression by Source Country Group: France (Dependent Variable: High Education Track Attendance)

\begin{tabular}{|c|c|c|c|c|c|}
\hline & Natives & $\begin{array}{l}\text { Immigrants from } \\
\text { Western Europe }\end{array}$ & $\begin{array}{l}\text { Immigrants from } \\
\text { Eastern Europe }\end{array}$ & $\begin{array}{l}\text { Immigrants from } \\
\text { Turkey / Middle East }\end{array}$ & $\begin{array}{c}\text { Immigrants from } \\
\text { Africa }\end{array}$ \\
\hline \multicolumn{6}{|l|}{ Number of siblings: (Reference: 1 sibling) } \\
\hline \multirow[t]{2}{*}{0 siblings } & $0.021^{*}$ & -0.029 & -0.054 & 0.078 & 0.057 \\
\hline & $(0.013)$ & $(0.045)$ & $(0.085)$ & $(0.162)$ & $(0.051)$ \\
\hline \multirow[t]{2}{*}{2 siblings } & $-0.023^{*}$ & -0.072 & 0.012 & 0.046 & 0.031 \\
\hline & $(0.013)$ & $(0.049)$ & (0.119) & $(0.113)$ & $(0.043)$ \\
\hline \multirow[t]{2}{*}{3 or more siblings } & $-0.099 * * *$ & $-0.200 * * *$ & $-0.311 * *$ & -0.160 & $-0.108 * * *$ \\
\hline & $(0.017)$ & $(0.055)$ & $(0.130)$ & $(0.113)$ & $(0.041)$ \\
\hline \multirow[t]{2}{*}{ Female } & $0.134 * * *$ & $0.216^{* * *}$ & $0.213^{* *}$ & $0.255^{* * *}$ & $0.149 * * *$ \\
\hline & $(0.010)$ & $(0.035)$ & $(0.082)$ & $(0.075)$ & $(0.029)$ \\
\hline \multirow[t]{2}{*}{ Age } & 0.005 & $0.029 * *$ & -0.009 & $0.076 * * *$ & $0.016^{*}$ \\
\hline & $(0.003)$ & $(0.012)$ & $(0.027)$ & $(0.028)$ & $(0.010)$ \\
\hline \multicolumn{6}{|c|}{ Mother's education: (Reference: medium education) } \\
\hline \multirow[t]{2}{*}{ Lower education } & $-0.074 * * *$ & $-0.130 * *$ & -0.041 & $-0.367 * *$ & -0.003 \\
\hline & $(0.015)$ & $(0.051)$ & $(0.137)$ & $(0.166)$ & $(0.051)$ \\
\hline \multirow[t]{2}{*}{ Higher education } & $0.233 * * *$ & $0.203^{* * *}$ & $0.391^{* * *}$ & -0.178 & $0.160 * * *$ \\
\hline & $(0.015)$ & $(0.054)$ & $(0.121)$ & $(0.210)$ & $(0.060)$ \\
\hline \multicolumn{6}{|c|}{ Father's education: (Reference: medium education) } \\
\hline \multirow[t]{2}{*}{ Lower education } & $-0.044 * * *$ & -0.023 & -0.187 & 0.090 & -0.050 \\
\hline & $(0.015)$ & $(0.052)$ & $(0.158)$ & $(0.166)$ & $(0.062)$ \\
\hline \multirow[t]{2}{*}{ Higher education } & $0.169 * * *$ & $0.158^{* * *}$ & 0.072 & 0.203 & 0.020 \\
\hline & $(0.015)$ & $(0.061)$ & $(0.161)$ & $(0.203)$ & $(0.069)$ \\
\hline \multirow[t]{2}{*}{ No information on educational status } & -0.000 & -0.002 & 0.100 & 0.184 & $-0.130 * *$ \\
\hline & $(0.016)$ & $(0.056)$ & (0.139) & $(0.181)$ & $(0.064)$ \\
\hline \multicolumn{6}{|c|}{ Monthly household income: (Reference: $€ 1500-€ 3200$ ) } \\
\hline \multirow[t]{2}{*}{$<€ 1500$} & $-0.068 * * *$ & -0.066 & -0.001 & 0.006 & $-0.122 * * *$ \\
\hline & $(0.014)$ & $(0.048)$ & $(0.118)$ & $(0.118)$ & $(0.040)$ \\
\hline \multirow[t]{2}{*}{$€ 3200-€ 7500$} & $0.046 * * *$ & -0.001 & 0.041 & $0.273^{*}$ & 0.005 \\
\hline & $(0.014)$ & $(0.052)$ & $(0.133)$ & $(0.138)$ & $(0.067)$ \\
\hline \multirow[t]{2}{*}{$>=€ 7500$} & 0.034 & 0.077 & 0.078 & $0.476 * *$ & $0.218^{* * *}$ \\
\hline & $(0.026)$ & $(0.104)$ & $(0.131)$ & $(0.218)$ & $(0.066)$ \\
\hline \multirow[t]{2}{*}{ No information on income } & $-0.058 * * *$ & -0.078 & -0.027 & -0.009 & $-0.120 * * *$ \\
\hline & $(0.015)$ & $(0.056)$ & $(0.108)$ & $(0.122)$ & $(0.039)$ \\
\hline Year fixed-effects & yes & yes & yes & yes & yes \\
\hline \multirow[t]{2}{*}{ Constant } & $0.386 * * *$ & -0.052 & 0.506 & $-1.003^{*}$ & 0.300 \\
\hline & $(0.065)$ & $(0.231)$ & (0.509) & $(0.591)$ & $(0.196)$ \\
\hline R-squared & 0.198 & 0.188 & 0.300 & 0.188 & 0.090 \\
\hline $\mathrm{N}$ & 11,510 & 835 & 141 & 145 & 1,507 \\
\hline
\end{tabular}

Notes: These are the coefficients of a linear probability model. The sample is restricted to students aged 16-20. The outcome variable is "high education track attendance". Reported standard errors are robust and clustered by household. * denotes statistical significance at the $10 \%$ level, $* *$ at the $5 \%$ level and *** at the $1 \%$ level. Source: French Labor Force Survey (Enquête de l'Emploi), author calculations 
Table A4b Regression by Source Country Group: Germany (Dependent Variable: High Education Track Attendance)

\begin{tabular}{|c|c|c|c|c|c|c|}
\hline & Natives & $\begin{array}{l}\text { Immigrants from } \\
\text { Western Europe }\end{array}$ & $\begin{array}{l}\text { Immigrants from } \\
\text { Eastern Europe }\end{array}$ & $\begin{array}{l}\text { Immigrants from } \\
\text { Turkey }\end{array}$ & $\begin{array}{l}\text { Immigrants from } \\
\text { Africa / Middle East }\end{array}$ & $\begin{array}{l}\text { Ethnic } \\
\text { Germans }\end{array}$ \\
\hline \multicolumn{7}{|l|}{ Number of siblings: (Reference: 1 sibling) } \\
\hline \multirow[t]{2}{*}{0 siblings } & -0.001 & 0.017 & 0.068 & -0.008 & $0.174^{* *}$ & -0.014 \\
\hline & $(0.009)$ & $(0.038)$ & $(0.046)$ & $(0.047)$ & $(0.079)$ & $(0.029)$ \\
\hline \multirow[t]{2}{*}{2 siblings } & $-0.048 * * *$ & -0.017 & -0.029 & -0.006 & 0.067 & $-0.080^{* *}$ \\
\hline & $(0.011)$ & $(0.049)$ & $(0.054)$ & $(0.039)$ & $(0.091)$ & $(0.033)$ \\
\hline \multirow[t]{2}{*}{3 or more siblings } & $-0.108^{* * *}$ & 0.011 & $-0.151 * * *$ & -0.009 & -0.079 & $-0.155^{* * *}$ \\
\hline & $(0.015)$ & $(0.051)$ & $(0.053)$ & $(0.042)$ & $(0.072)$ & $(0.048)$ \\
\hline \multirow[t]{2}{*}{ Female } & $0.104 * * *$ & 0.006 & $0.063^{*}$ & $0.049 *$ & $0.090^{*}$ & $0.133^{* * *}$ \\
\hline & $(0.007)$ & $(0.037)$ & $(0.034)$ & $(0.029)$ & $(0.052)$ & $(0.026)$ \\
\hline \multirow[t]{2}{*}{ Age } & 0.001 & $0.019 *$ & -0.003 & -0.000 & 0.023 & -0.004 \\
\hline & $(0.002)$ & $(0.010)$ & $(0.010)$ & $(0.010)$ & $(0.018)$ & $(0.008)$ \\
\hline \multicolumn{7}{|c|}{ Mother's education: (Reference: medium education) } \\
\hline \multirow[t]{2}{*}{ Lower education } & $-0.168 * * *$ & $-0.081^{* *}$ & -0.030 & $-0.104 * *$ & 0.009 & $-0.090 * * *$ \\
\hline & (0.015) & (0.041) & $(0.050)$ & $(0.047)$ & $(0.074)$ & $(0.032)$ \\
\hline \multirow[t]{2}{*}{ Higher education } & $0.228 * * *$ & $0.241^{* * *}$ & $0.248^{* * *}$ & 0.050 & $0.235^{* * *}$ & $0.171^{* * *}$ \\
\hline & $(0.011)$ & $(0.049)$ & $(0.061)$ & $(0.088)$ & $(0.079)$ & $(0.036)$ \\
\hline \multirow[t]{2}{*}{ No information on educational status } & $-0.033 * *$ & -0.143 & 0.027 & -0.131 & -0.083 & $-0.200 * * *$ \\
\hline & $(0.016)$ & $(0.090)$ & $(0.096)$ & $(0.120)$ & $(0.124)$ & $(0.074)$ \\
\hline \multicolumn{7}{|c|}{ Father's education: (Reference: medium education) } \\
\hline \multicolumn{7}{|l|}{ Lower education } \\
\hline & $-0.081 * * *$ & $-0.081^{*}$ & -0.021 & -0.033 & -0.116 & $-0.087^{*}$ \\
\hline \multirow[t]{2}{*}{ Higher education } & $(0.026)$ & $(0.042)$ & $(0.048)$ & $(0.045)$ & $(0.081)$ & $(0.046)$ \\
\hline & $0.269 * * *$ & $0.263^{* * *}$ & $0.153^{* *}$ & $0.162^{* *}$ & -0.067 & $0.226 * * *$ \\
\hline \multirow[t]{2}{*}{ No information on educational status } & $(0.011)$ & $(0.058)$ & $(0.064)$ & $(0.071)$ & $(0.087)$ & $(0.036)$ \\
\hline & $0.030 * * *$ & 0.005 & 0.063 & $-0.238 * * *$ & -0.055 & -0.032 \\
\hline \multicolumn{7}{|c|}{ Monthly household income: (Reference: $€ 1500-€ 3200$ ) } \\
\hline \multirow[t]{2}{*}{$<€ 1500$} & $-0.052 * * *$ & -0.034 & $-0.103 * *$ & -0.030 & -0.065 & -0.021 \\
\hline & $(0.015)$ & $(0.053)$ & $(0.049)$ & $(0.041)$ & $(0.070)$ & $(0.037)$ \\
\hline \multirow[t]{2}{*}{$€ 3200-€ 7500$} & 0.010 & 0.021 & $0.088 *$ & $-0.055^{*}$ & -0.025 & 0.005 \\
\hline & $(0.008)$ & $(0.037)$ & $(0.048)$ & $(0.032)$ & $(0.072)$ & $(0.023)$ \\
\hline \multirow[t]{2}{*}{$>=€ 7500$} & $0.088 * * *$ & 0.055 & $0.167 *$ & -0.195 & 0.009 & $0.165^{* *}$ \\
\hline & $(0.017)$ & $(0.076)$ & $(0.090)$ & $(0.129)$ & $(0.201)$ & $(0.064)$ \\
\hline \multirow[t]{2}{*}{ No information on income } & $0.035^{* *}$ & 0.052 & -0.030 & 0.048 & -0.027 & 0.048 \\
\hline & $(0.014)$ & $(0.058)$ & $(0.053)$ & $(0.051)$ & $(0.074)$ & $(0.056)$ \\
\hline Year fixed-effects & yes & yes & yes & yes & yes & yes \\
\hline \multirow[t]{2}{*}{ Constant } & $0.306^{* * *}$ & 0.023 & 0.259 & 0.179 & 0.170 & 0.193 \\
\hline & $(0.044)$ & $(0.180)$ & $(0.196)$ & $(0.185)$ & $(0.357)$ & $(0.173)$ \\
\hline R-squared & 0.172 & 0.231 & 0.156 & 0.053 & 0.168 & 0.151 \\
\hline $\mathrm{N}$ & 37,514 & 1,474 & 1,723 & 2,015 & 511 & 2,855 \\
\hline
\end{tabular}

Notes: These are the coefficients of a linear probability model. The sample is restricted to students aged 17-20. The outcome variable is "high education track attendance". Reported standard errors are robust and clustered by household. * denotes statistical significance at the $10 \%$ level, $* *$ at the $5 \%$ level and $* * *$ at the $1 \%$ level. Source: German Microcensus (2005 and 2008) and GSOEP, author calculations. 
Table A5: Results of the Blinder-Oaxaca Decomposition Using the Number of Siblings Based on the Mother's Number of Births (Microcensus 2008)

\begin{tabular}{|c|c|c|c|c|c|c|c|}
\hline & \multicolumn{7}{|c|}{ Microcensus 2008} \\
\hline & $\begin{array}{l}\text { First generation } \\
\text { immigrants }\end{array}$ & $\begin{array}{l}\text { Second generation } \\
\text { immigrants }\end{array}$ & $\begin{array}{l}\text { Immigrants from } \\
\text { Western Europe }\end{array}$ & $\begin{array}{l}\text { Immigrants from } \\
\text { Eastern Europe }\end{array}$ & $\begin{array}{l}\text { Immigrants from } \\
\text { Turkey }\end{array}$ & $\begin{array}{l}\text { Immigrants from } \\
\text { Africa / Middle East }\end{array}$ & Ethnic Germans \\
\hline & Coeff. & Coeff. & Coeff. & Coeff. & Coeff. & Coeff. & Coeff. \\
\hline High education track (natives) & 43.9 & 43.9 & 43.9 & 43.9 & 43.9 & 43.9 & 43.9 \\
\hline High education track (immigrants) & 31.1 & 38.5 & 44.9 & 33.7 & 25.8 & 28.6 & 36.1 \\
\hline Gap (difference natives-immigrants) & 12.7 & 5.4 & -1.1 & 10.1 & 18.1 & 15.3 & 7.8 \\
\hline Gap explained & 9.9 & 13.5 & 9.1 & 5.9 & 32.6 & 14.6 & 3.6 \\
\hline \multicolumn{8}{|l|}{ Contributions from differences in } \\
\hline \multirow[t]{2}{*}{ Number of siblings } & $1.6^{* * *}$ & $1.9 * * *$ & $0.9 * * *$ & $0.7^{* * *}$ & $3.7^{* * *}$ & $4.6 * * *$ & $0.8 * * *$ \\
\hline & $(0.2)$ & $(0.2)$ & $(0.2)$ & $(0.2)$ & $(0.4)$ & $(0.7)$ & $(0.2)$ \\
\hline \multirow[t]{2}{*}{ Parents' educational background } & $7.1 * * *$ & $11.0 * * *$ & $8.1 * * *$ & $3.8^{* * *}$ & $27.7^{* * *}$ & $7.4^{* * *}$ & $2.5^{* * *}$ \\
\hline & $(0.9)$ & $(0.9)$ & $(1.5)$ & $(1.2)$ & $(1.4)$ & $(2.5)$ & $(0.8)$ \\
\hline \multirow[t]{2}{*}{ Parents' income } & $1.2 * * *$ & $0.5^{* * *}$ & 0.3 & $1.3^{* * *}$ & $0.9 * * *$ & $1.9 * * *$ & $0.5 * * *$ \\
\hline & $(0.3)$ & $(0.2)$ & $(0.2)$ & $(0.3)$ & $(0.3)$ & $(0.5)$ & $(0.2)$ \\
\hline \multirow[t]{2}{*}{ Age and gender } & 0.0 & 0.1 & -0.2 & 0.2 & 0.2 & $0.7^{*}$ & -0.1 \\
\hline & $(0.2)$ & $(0.1)$ & $(0.3)$ & $(0.2)$ & $(0.2)$ & $(0.4)$ & $(0.2)$ \\
\hline No. of observations (immigrants) & 1,512 & 2,243 & 479 & 635 & 876 & 229 & 1,156 \\
\hline
\end{tabular}

Notes: These are the results of a Blinder-Oaxaca Decomposition. Characteristics evaluated at native coefficients. The sample is restricted to students aged $17-20$. The outcome variable is "high education track attendance". Reported standard errors are robust and clustered by household. * denotes statistical significance at the $10 \%$ level, $* *$ at the $5 \%$ level and ${ }^{* * *}$ at the $1 \%$ level. The number of observations for natives equals 13,155.

Source: German Microcensus (2008), author calculations. 
Table A6a: Results of the Blinder-Oaxaca Decomposition for 16/17 to 18 Year Old Individuals

\begin{tabular}{|c|c|c|c|c|c|c|}
\hline & \multirow[b]{2}{*}{$\begin{array}{l}\text { First generation } \\
\text { immigrants }\end{array}$} & \multicolumn{5}{|c|}{ France } \\
\hline & & $\begin{array}{l}\text { Second generation } \\
\text { immigrants }\end{array}$ & $\begin{array}{l}\text { Immigrants from } \\
\text { Western Europe }\end{array}$ & $\begin{array}{l}\text { Immigrants from } \\
\text { Eastern Europe }\end{array}$ & $\begin{array}{l}\text { Immigrants from } \\
\text { Turkey / Middle East }\end{array}$ & $\begin{array}{l}\text { Immigrants from } \\
\text { Africa }\end{array}$ \\
\hline & Coeff. & Coeff. & Coeff. & Coeff. & Coeff. & Coeff. \\
\hline High education track (natives) & 60.0 & 60.0 & 60.0 & 60.0 & 60.0 & 60.0 \\
\hline High education track (immigrants) & 43.0 & 54.1 & 50.0 & 59.9 & 35.3 & 49.5 \\
\hline Gap (difference natives-immigrants) & 17.0 & 5.9 & 10.0 & 0.1 & 24.6 & 10.5 \\
\hline Gap explained & 9.6 & 11.7 & 7.7 & -2.6 & 19.7 & 16.0 \\
\hline \multicolumn{7}{|l|}{ Contributions from differences in } \\
\hline \multirow[t]{2}{*}{ Number of siblings } & $1.7^{* * *}$ & $2.2 * * *$ & 0.1 & 0.2 & $3.0 * * *$ & $3.0 * * *$ \\
\hline & $(0.5)$ & $(0.4)$ & $(0.2)$ & $(0.5)$ & $(0.8)$ & $(0.6)$ \\
\hline \multirow[t]{2}{*}{ Parents' educational background } & $5.7^{* * *}$ & $7.6 * * *$ & $6.5^{* * *}$ & $-4.8 *$ & $13.5 * * *$ & $10.3^{* * *}$ \\
\hline & $(1.8)$ & $(0.8)$ & $(1.0)$ & $(2.6)$ & $(2.1)$ & $(0.9)$ \\
\hline \multirow[t]{2}{*}{ Parents' income } & $2.7^{* * *}$ & $1.7^{* * *}$ & $0.9^{* * *}$ & $1.7^{* * *}$ & $3.3^{* * *}$ & $2.7^{* * *}$ \\
\hline & $(0.6)$ & $(0.3)$ & $(0.3)$ & $(0.6)$ & $(0.8)$ & $(0.5)$ \\
\hline \multirow[t]{2}{*}{ Age and gender } & -0.8 & 0.1 & 0.2 & 0.1 & -0.5 & -0.2 \\
\hline & $(0.5)$ & $(0.2)$ & $(0.4)$ & $(0.8)$ & $(0.8)$ & $(0.3)$ \\
\hline \multirow[t]{2}{*}{ Year dummy variables } & 0.3 & 0.1 & 0.1 & 0.2 & 0.5 & 0.1 \\
\hline & $(0.2)$ & $(0.1)$ & $(0.1)$ & $(0.3)$ & $(0.3)$ & $(0.1)$ \\
\hline No. of observations (immigrants) & 247 & 1,397 & 508 & 87 & 87 & 959 \\
\hline
\end{tabular}


Table A6b: Results of the Blinder-Oaxaca Decomposition for 16/17 to 18 Year Old Individuals (continued)

\begin{tabular}{|c|c|c|c|c|c|c|c|}
\hline & \multicolumn{7}{|c|}{ Germany } \\
\hline & $\begin{array}{c}\text { First generation } \\
\text { immigrants }\end{array}$ & $\begin{array}{l}\text { Second generation } \\
\text { immigrants }\end{array}$ & $\begin{array}{l}\text { Immigrants from } \\
\text { Western Europe }\end{array}$ & $\begin{array}{l}\text { Immigrants from } \\
\text { Eastern Europe }\end{array}$ & $\begin{array}{c}\text { Immigrants from } \\
\text { Turkey }\end{array}$ & $\begin{array}{c}\text { Immigrants from } \\
\text { Africa / Middle East }\end{array}$ & Ethnic Germans \\
\hline & Coeff. & Coeff. & Coeff. & Coeff. & Coeff. & Coeff. & Coeff. \\
\hline High education track (natives) & 47.0 & 47.0 & 47.0 & 47.0 & 47.0 & 47.0 & 47.0 \\
\hline High education track (immigrants) & 36.7 & 41.5 & 40.9 & 41.0 & 32.0 & 39.9 & 40.3 \\
\hline Gap (difference natives-immigrants) & 10.3 & 5.5 & 6.1 & 6.0 & 15.0 & 7.1 & 6.7 \\
\hline Gap explained & 4.6 & 10.2 & 6.4 & 2.4 & 25.8 & 9.2 & 0.6 \\
\hline \multicolumn{8}{|l|}{ Contributions from differences in } \\
\hline \multirow[t]{2}{*}{ Number of siblings } & $1.4^{* * *}$ & $1.3 * * *$ & $1.0 * * *$ & $0.4 * *$ & $3.0 * * *$ & $3.0 * * *$ & $0.4^{* * *}$ \\
\hline & $(0.3)$ & $(0.2)$ & $(0.3)$ & $(0.2)$ & $(0.5)$ & $(0.6)$ & $(0.2)$ \\
\hline \multirow[t]{2}{*}{ Parents' educational background } & $2.4 * *$ & $7.5 * * *$ & $4.3 * *$ & 0.1 & $20.8 * * *$ & 2.8 & 0.6 \\
\hline & $(1.0)$ & $(0.9)$ & $(1.7)$ & $(1.2)$ & $(1.5)$ & $(2.4)$ & $(0.8)$ \\
\hline \multirow[t]{2}{*}{ Parents' income } & $1.0 * * *$ & $0.4^{* *}$ & 0.0 & $0.8^{* * *}$ & $0.8 * * *$ & $1.3 * * *$ & $0.5 * * *$ \\
\hline & $(0.3)$ & $(0.1)$ & $(0.2)$ & $(0.2)$ & $(0.3)$ & $(0.5)$ & $(0.2)$ \\
\hline \multirow[t]{2}{*}{ Age and gender } & 0.0 & $-0.3 *$ & -0.3 & 0.2 & -0.1 & 0.3 & $-0.4 * *$ \\
\hline & $(0.2)$ & $(0.1)$ & $(0.3)$ & $(0.2)$ & $(0.2)$ & $(0.5)$ & $(0.2)$ \\
\hline \multirow[t]{2}{*}{ Year dummy variables } & -0.2 & $1.2 * * *$ & $1.4 * * *$ & $0.9 * *$ & $1.2 * * *$ & $1.7 * *$ & $-0.6 * * *$ \\
\hline & $(0.2)$ & $(0.2)$ & $(0.4)$ & $(0.4)$ & $(0.4)$ & $(0.8)$ & $(0.2)$ \\
\hline No. of observations (immigrants) & 1,743 & 2,960 & 766 & 877 & 1,014 & 273 & 1,277 \\
\hline
\end{tabular}

Notes: These are the results of a Blinder-Oaxaca Decomposition. Characteristics evaluated at immigrant coefficients. The French sample is restricted to students aged $16-18$, in the German sample students are aged 17-18. The outcome variable is "high education track attendance". Reported standard errors are robust and clustered by household. * denotes statistical significance at the $10 \%$ level, ** at the $5 \%$ level and ${ }^{* * *}$ at the $1 \%$ level. In France, the number of observations of natives is 7.461 for natives and in Germany 18.909 .

Source: French Labor Force Survey (Enquête de l'Emploi) and German Microcensus (2005 and 2008) and GSOEP, author calculations. 


\section{Table A7 Parents' Intermarriage in the Second Generation}

\begin{tabular}{|c|c|c|}
\hline Share of second generation migrants (in percent) with: & France & Germany \\
\hline One parent Western European origin and one parent native & 65.5 & 51.0 \\
\hline Both parents Western European origin & 31.9 & 44.9 \\
\hline One parent Western European origin and one parent non-Western European, non-native origin & 2.6 & 4.1 \\
\hline One parent Eastern European origin and one parent native & 61.3 & 37.6 \\
\hline Both parents Eastern European origin & 36.6 & 56.3 \\
\hline One parent Eastern European origin and one parent non-Eastern European, non-native origin & 2.1 & 6.1 \\
\hline One parent Turkish (Fr: or Middle Eastern) origin and one parent native & 17.5 & 1.5 \\
\hline Both parents Turkish (Fr: or Middle Eastern) origin & 81.0 & 97.4 \\
\hline One parent Turkish (Fr: or Middle Eastern) origin and one parent non-Turkish (Fr: or non-Middle Eastern), & 1.5 & 1.1 \\
\hline One parent African (Ger: or Middle Eastern) origin and one parent native & 23.6 & 19.5 \\
\hline Both parents African (Ger: or Middle Eastern) origin & 75.2 & 72.7 \\
\hline One parent African (Ger: or Middle Eastern) origin and one parent non-African (Ger: or Middle Eastern), non- & 1.3 & 7.8 \\
\hline One parent other origin and one parent native & 36.6 & 62.2 \\
\hline Both parents other origin & 61.2 & 36.1 \\
\hline One parent other origin and one parent non-other, non-native origin & 2.2 & 1.7 \\
\hline One parent ethnic German and one parent native & - & 44.7 \\
\hline Both parents ethnic Germans & - & 49.9 \\
\hline One parent ethnic German and one parent non-other, non-native origin & - & 5.4 \\
\hline
\end{tabular}

Source: French Labor Force Survey (Enquête de l'Emploi) and German Microcensus (2005 and 2008) and GSOEP, author calculations. 
Table A8a Regression Results by Source Country Group Including Parental Intermarriage Indicator: France

\begin{tabular}{|c|c|c|c|c|c|}
\hline & Natives & $\begin{array}{l}\text { Immigrants from } \\
\text { Western Europe }\end{array}$ & $\begin{array}{l}\text { Immigrants from } \\
\text { Eastern Europe }\end{array}$ & $\begin{array}{c}\text { Immigrants from } \\
\text { Turkey / Middle East }\end{array}$ & $\begin{array}{l}\text { Immigrants } \\
\text { from Africa }\end{array}$ \\
\hline \multicolumn{6}{|l|}{ Number of siblings: (Reference: 1 sibling) } \\
\hline 0 siblings & $\begin{array}{l}0.021^{*} \\
(0.013)\end{array}$ & $\begin{array}{l}-0.030 \\
(0.046)\end{array}$ & $\begin{array}{l}-0.096 \\
(0.095)\end{array}$ & $\begin{array}{c}0.196 \\
(0.185)\end{array}$ & $\begin{array}{c}0.034 \\
(0.059)\end{array}$ \\
\hline 2 siblings & $\begin{array}{l}-0.023^{*} \\
(0.013)\end{array}$ & $\begin{array}{l}-0.063 \\
(0.049)\end{array}$ & $\begin{array}{l}-0.084 \\
(0.128)\end{array}$ & $\begin{array}{c}0.121 \\
(0.125)\end{array}$ & $\begin{array}{c}0.007 \\
(0.049)\end{array}$ \\
\hline 3 or more siblings & $\begin{array}{c}-0.099^{* * *} \\
(0.017)\end{array}$ & $\begin{array}{c}-0.226 * * * \\
(0.054)\end{array}$ & $\begin{array}{c}-0.464^{* * *} \\
(0.144)\end{array}$ & $\begin{array}{l}-0.112 \\
(0.133)\end{array}$ & $\begin{array}{c}-0.123^{* * *} \\
(0.046)\end{array}$ \\
\hline Female & $\begin{array}{c}0.134 * * * \\
(0.010)\end{array}$ & $\begin{array}{c}0.219^{* * *} \\
(0.036)\end{array}$ & $\begin{array}{l}0.222^{* *} \\
(0.085)\end{array}$ & $\begin{array}{l}0.238^{* *} \\
(0.091)\end{array}$ & $\begin{array}{c}0.144 * * * \\
(0.033)\end{array}$ \\
\hline Age & $\begin{array}{c}0.005 \\
(0.003)\end{array}$ & $\begin{array}{c}0.029^{* *} \\
(0.012)\end{array}$ & $\begin{array}{l}-0.010 \\
(0.031)\end{array}$ & $\begin{array}{c}0.081 * * * \\
(0.029)\end{array}$ & $\begin{array}{c}0.011 \\
(0.011)\end{array}$ \\
\hline \multicolumn{6}{|c|}{ Mother's education: (Reference: medium education) } \\
\hline Lower education & $\begin{array}{c}-0.074^{* * *} \\
(0.015)\end{array}$ & $\begin{array}{c}-0.149 * * * \\
(0.052)\end{array}$ & $\begin{array}{c}0.018 \\
(0.142)\end{array}$ & $\begin{array}{c}-0.356^{* *} \\
(0.172)\end{array}$ & $\begin{array}{l}-0.019 \\
(0.057)\end{array}$ \\
\hline Higher education & $\begin{array}{c}0.233^{* * *} \\
(0.015)\end{array}$ & $\begin{array}{c}0.203^{* * *} \\
(0.056)\end{array}$ & $\begin{array}{l}0.300^{* *} \\
(0.132)\end{array}$ & $\begin{array}{l}-0.121 \\
(0.237)\end{array}$ & $\begin{array}{c}0.165^{* *} \\
(0.064)\end{array}$ \\
\hline \multicolumn{6}{|l|}{ Father's education: (Reference: medium education) } \\
\hline Lower education & $\begin{array}{c}-0.044^{* * *} \\
(0.015)\end{array}$ & $\begin{array}{l}-0.022 \\
(0.052)\end{array}$ & $\begin{array}{l}-0.236 \\
(0.153)\end{array}$ & $\begin{array}{c}0.092 \\
(0.158)\end{array}$ & $\begin{array}{l}-0.080 \\
(0.061)\end{array}$ \\
\hline Higher education & $\begin{array}{c}0.169 * * * \\
(0.015)\end{array}$ & $\begin{array}{c}0.167^{* * *} \\
(0.061)\end{array}$ & $\begin{array}{c}0.147 \\
(0.160)\end{array}$ & $\begin{array}{c}0.157 \\
(0.201)\end{array}$ & $\begin{array}{c}0.017 \\
(0.067)\end{array}$ \\
\hline No information on educational status & $\begin{array}{l}-0.000 \\
(0.016)\end{array}$ & $\begin{array}{c}0.011 \\
(0.067)\end{array}$ & $\begin{array}{c}0.165 \\
(0.169)\end{array}$ & $\begin{array}{l}-0.062 \\
(0.206)\end{array}$ & $\begin{array}{l}-0.104 \\
(0.076)\end{array}$ \\
\hline \multicolumn{6}{|c|}{ Monthly household income: (Reference: $€ 1500-€ 3200$ ) } \\
\hline$<€ 1500$ & $\begin{array}{c}-0.068^{* * *} \\
(0.014)\end{array}$ & $\begin{array}{l}-0.037 \\
(0.049)\end{array}$ & $\begin{array}{c}0.079 \\
(0.138)\end{array}$ & $\begin{array}{c}0.010 \\
(0.127)\end{array}$ & $\begin{array}{c}-0.097^{* *} \\
(0.042)\end{array}$ \\
\hline$€ 3200-€ 7500$ & $\begin{array}{c}0.046^{* * *} \\
(0.014)\end{array}$ & $\begin{array}{c}0.005 \\
(0.051)\end{array}$ & $\begin{array}{c}0.003 \\
(0.134)\end{array}$ & $\begin{array}{c}0.233 \\
(0.155)\end{array}$ & $\begin{array}{c}0.016 \\
(0.067)\end{array}$ \\
\hline$>=€ 7500$ & $\begin{array}{c}0.034 \\
(0.026)\end{array}$ & $\begin{array}{c}0.087 \\
(0.107)\end{array}$ & $\begin{array}{c}0.173 \\
(0.157)\end{array}$ & $\begin{array}{l}0.491^{*} \\
(0.250)\end{array}$ & $\begin{array}{l}0.136^{*} \\
(0.076)\end{array}$ \\
\hline No information on income & $\begin{array}{c}-0.058^{* * *} \\
(0.015)\end{array}$ & $\begin{array}{l}-0.068 \\
(0.058)\end{array}$ & $\begin{array}{l}-0.048 \\
(0.126)\end{array}$ & $\begin{array}{c}0.081 \\
(0.127)\end{array}$ & $\begin{array}{c}-0.111^{* * *} \\
(0.041)\end{array}$ \\
\hline \multicolumn{6}{|c|}{ Immigrant generation: (Reference: second generation) } \\
\hline First generation & $\begin{array}{l}- \\
-\end{array}$ & $\begin{array}{l}-0.120 \\
(0.081)\end{array}$ & $\begin{array}{l}-0.094 \\
(0.127)\end{array}$ & $\begin{array}{l}-0.087 \\
(0.118)\end{array}$ & $\begin{array}{c}-0.183^{* * *} \\
(0.044)\end{array}$ \\
\hline Third generation & - & $\begin{array}{l}-0.073 \\
(0.068)\end{array}$ & $\begin{array}{l}-0.141 \\
(0.147)\end{array}$ & - & $\begin{array}{c}-0.169 * * \\
(0.069)\end{array}$ \\
\hline Second generation and parents intermarried & $\begin{array}{l}- \\
-\end{array}$ & $\begin{array}{l}-0.054 \\
(0.049)\end{array}$ & $\begin{array}{c}0.133 \\
(0.109)\end{array}$ & $\begin{array}{c}0.060 \\
(0.127)\end{array}$ & $\begin{array}{c}-0.111^{* *} \\
(0.047)\end{array}$ \\
\hline Year fixed-effects & yes & yes & yes & yes & yes \\
\hline Constant & $\begin{array}{c}0.386^{* * *} \\
(0.065)\end{array}$ & $\begin{array}{l}-0.007 \\
(0.237)\end{array}$ & $\begin{array}{c}0.626 \\
(0.615)\end{array}$ & $\begin{array}{l}-1.157^{*} \\
(0.614)\end{array}$ & $\begin{array}{l}0.502^{* *} \\
(0.216)\end{array}$ \\
\hline R-squared & 0.198 & 0.200 & 0.274 & 0.211 & 0.106 \\
\hline $\mathrm{N}$ & 11,510 & 784 & 127 & 124 & 1,275 \\
\hline
\end{tabular}

Notes: These are the coefficients of a linear probability model. The sample is restricted to students aged 16-20. The outcome variable is "high education track attendance". Reported standard errors are robust and clustered by household. * denotes statistical significance at the $10 \%$ level, $* *$ at the $5 \%$ level and $* * *$ at the $1 \%$ level.

Source: French Labor Force Survey (Enquête de l'Emploi), author calculations. 
Table A8b Regression Results by Source Country Group Including Parental Intermarriage Indicator: Germany

\begin{tabular}{|c|c|c|c|c|c|c|}
\hline & Natives & $\begin{array}{l}\text { Immigrants from } \\
\text { Western Europe }\end{array}$ & $\begin{array}{l}\text { Immigrants from } \\
\text { Eastern Europe }\end{array}$ & $\begin{array}{c}\text { Immigrants from } \\
\text { Turkey } \\
\end{array}$ & $\begin{array}{c}\text { Immigrants from } \\
\text { Africa / Middle East }\end{array}$ & $\begin{array}{c}\text { Ethnic } \\
\text { Germans } \\
\end{array}$ \\
\hline \multicolumn{7}{|l|}{ Number of siblings: (Reference: 1 sibling) } \\
\hline 0 siblings & $\begin{array}{l}-0.001 \\
(0.009)\end{array}$ & $\begin{array}{c}0.023 \\
(0.040)\end{array}$ & $\begin{array}{c}0.020 \\
(0.043)\end{array}$ & $\begin{array}{c}0.010 \\
(0.050)\end{array}$ & $\begin{array}{c}0.128 \\
(0.082)\end{array}$ & $\begin{array}{l}-0.020 \\
(0.029)\end{array}$ \\
\hline 2 siblings & $\begin{array}{c}-0.048^{* * *} \\
(0.011)\end{array}$ & $\begin{array}{l}-0.016 \\
(0.050)\end{array}$ & $\begin{array}{l}-0.019 \\
(0.058)\end{array}$ & $\begin{array}{c}0.007 \\
(0.041)\end{array}$ & $\begin{array}{c}0.048 \\
(0.096)\end{array}$ & $\begin{array}{c}-0.080 * * \\
(0.033)\end{array}$ \\
\hline 3 or more siblings & $\begin{array}{c}-0.108^{* * *} \\
(0.015)\end{array}$ & $\begin{array}{c}0.026 \\
(0.058)\end{array}$ & $\begin{array}{c}-0.129 * * \\
(0.050)\end{array}$ & $\begin{array}{l}-0.006 \\
(0.044)\end{array}$ & $\begin{array}{l}-0.115 \\
(0.074)\end{array}$ & $\begin{array}{l}-0.146 * * * \\
(0.049)\end{array}$ \\
\hline Female & $\begin{array}{c}0.104^{* * *} \\
(0.007)\end{array}$ & $\begin{array}{l}-0.023 \\
(0.039)\end{array}$ & $\begin{array}{c}0.057 \\
(0.035)\end{array}$ & $\begin{array}{c}0.032 \\
(0.030)\end{array}$ & $\begin{array}{l}0.080 \\
(0.054)\end{array}$ & $\begin{array}{l}0.130 * * * \\
(0.026)\end{array}$ \\
\hline Age & $\begin{array}{c}0.001 \\
(0.002)\end{array}$ & $\begin{array}{l}0.019^{*} \\
(0.011)\end{array}$ & $\begin{array}{c}0.005 \\
(0.011)\end{array}$ & $\begin{array}{c}0.002 \\
(0.011)\end{array}$ & $\begin{array}{c}0.021 \\
(0.020)\end{array}$ & $\begin{array}{c}0.001 \\
(0.008)\end{array}$ \\
\hline \multicolumn{7}{|c|}{ Mother's education: (Reference: medium education) } \\
\hline Lower education & $\begin{array}{c}-0.168^{* * *} \\
(0.015)\end{array}$ & $\begin{array}{l}-0.061 \\
(0.042)\end{array}$ & $\begin{array}{l}-0.002 \\
(0.048)\end{array}$ & $\begin{array}{c}-0.125^{* *} \\
(0.049)\end{array}$ & $\begin{array}{l}-0.019 \\
(0.077)\end{array}$ & $\begin{array}{l}-0.080^{* *} \\
(0.032)\end{array}$ \\
\hline Higher education & $\begin{array}{c}0.228^{* * *} \\
(0.011)\end{array}$ & $\begin{array}{c}0.226 * * * \\
(0.053)\end{array}$ & $\begin{array}{c}0.277^{* * *} \\
(0.061)\end{array}$ & $\begin{array}{c}0.054 \\
(0.122)\end{array}$ & $\begin{array}{c}0.256^{* * *} \\
(0.085)\end{array}$ & $\begin{array}{l}0.152^{* * *} \\
(0.036)\end{array}$ \\
\hline No information on educational status & $\begin{array}{c}-0.033^{* *} \\
(0.016)\end{array}$ & $\begin{array}{l}-0.039 \\
(0.134)\end{array}$ & $\begin{array}{l}-0.019 \\
(0.092)\end{array}$ & $\begin{array}{l}-0.248^{*} \\
(0.143)\end{array}$ & $\begin{array}{l}-0.066 \\
(0.143)\end{array}$ & $\begin{array}{l}-0.181^{* *} \\
(0.074)\end{array}$ \\
\hline \multicolumn{7}{|c|}{ Father's education: (Reference: medium education) } \\
\hline Lower education & $\begin{array}{c}-0.081 * * * \\
(0.026)\end{array}$ & $\begin{array}{c}-0.081^{*} \\
(0.042)\end{array}$ & $\begin{array}{l}-0.021 \\
(0.048)\end{array}$ & $\begin{array}{c}-0.033 \\
(0.045)\end{array}$ & $\begin{array}{l}-0.116 \\
(0.081)\end{array}$ & $\begin{array}{l}-0.087^{*} \\
(0.046)\end{array}$ \\
\hline Higher education & $\begin{array}{c}0.269 * * * \\
(0.011)\end{array}$ & $\begin{array}{c}0.263^{* * *} \\
(0.058)\end{array}$ & $\begin{array}{l}0.153^{* *} \\
(0.064)\end{array}$ & $\begin{array}{c}0.162 * * \\
(0.071)\end{array}$ & $\begin{array}{l}-0.067 \\
(0.087)\end{array}$ & $\begin{array}{l}0.226 * * * \\
(0.036)\end{array}$ \\
\hline No information on educational status & $\begin{array}{c}0.030^{* * *} \\
(0.010)\end{array}$ & $\begin{array}{c}0.005 \\
(0.086)\end{array}$ & $\begin{array}{c}0.063 \\
(0.051)\end{array}$ & $\begin{array}{c}-0.238^{* * *} \\
(0.071)\end{array}$ & $\begin{array}{l}-0.055 \\
(0.115)\end{array}$ & $\begin{array}{l}-0.032 \\
(0.040)\end{array}$ \\
\hline \multicolumn{7}{|c|}{ Monthly household income: (Reference: $€ 1500-€ 3200$ ) } \\
\hline$<€ 1500$ & $\begin{array}{c}-0.052 * * * \\
(0.015)\end{array}$ & $\begin{array}{l}-0.076 \\
(0.060)\end{array}$ & $\begin{array}{l}-0.082 * \\
(0.048)\end{array}$ & $\begin{array}{c}-0.075^{*} \\
(0.045)\end{array}$ & $\begin{array}{l}-0.080 \\
(0.074)\end{array}$ & $\begin{array}{l}-0.004 \\
(0.038)\end{array}$ \\
\hline$€ 3200-€ 7500$ & $\begin{array}{c}0.010 \\
(0.008)\end{array}$ & $\begin{array}{c}0.034 \\
(0.039)\end{array}$ & $\begin{array}{c}0.053 \\
(0.041)\end{array}$ & $\begin{array}{l}-0.058^{*} \\
(0.033)\end{array}$ & $\begin{array}{l}-0.042 \\
(0.071)\end{array}$ & $\begin{array}{l}-0.017 \\
(0.024)\end{array}$ \\
\hline$>=€ 7500$ & $\begin{array}{c}0.088^{* * *} \\
(0.017)\end{array}$ & $\begin{array}{c}0.021 \\
(0.080)\end{array}$ & $\begin{array}{c}0.079 \\
(0.097)\end{array}$ & $\begin{array}{l}-0.198 \\
(0.131)\end{array}$ & $\begin{array}{l}0.036 \\
(0.212)\end{array}$ & $\begin{array}{l}0.138^{* *} \\
(0.064)\end{array}$ \\
\hline No information on income & $\begin{array}{l}0.035^{* *} \\
(0.014)\end{array}$ & $\begin{array}{c}0.045 \\
(0.061)\end{array}$ & $\begin{array}{l}-0.025 \\
(0.053)\end{array}$ & $\begin{array}{c}0.053 \\
(0.056)\end{array}$ & $\begin{array}{l}-0.036 \\
(0.077)\end{array}$ & $\begin{array}{c}0.039 \\
(0.055)\end{array}$ \\
\hline \multicolumn{7}{|c|}{ Immigrant generation: (Reference: second generation) } \\
\hline First generation & - & $\begin{array}{c}0.049 \\
(0.052)\end{array}$ & $\begin{array}{c}-0.082^{* *} \\
(0.041)\end{array}$ & $\begin{array}{c}0.038 \\
(0.057)\end{array}$ & $\begin{array}{c}-0.113^{* *} \\
(0.055)\end{array}$ & $\begin{array}{l}-0.069 * * \\
(0.029)\end{array}$ \\
\hline Third generation & - & $\begin{array}{c}-0.161^{* *} \\
(0.070)\end{array}$ & $\begin{array}{l}-0.110 \\
(0.118)\end{array}$ & $\begin{array}{c}-0.230^{* *} \\
(0.099)\end{array}$ & $\begin{array}{c}-0.503^{* * *} \\
(0.148)\end{array}$ & $\begin{array}{c}0.095 \\
(0.406)\end{array}$ \\
\hline Second generation and parents intermarried & $\begin{array}{l}- \\
-\end{array}$ & $\begin{array}{c}0.043 \\
(0.046)\end{array}$ & $\begin{array}{c}0.112 \\
(0.070)\end{array}$ & $\begin{array}{c}0.013 \\
(0.091)\end{array}$ & $\begin{array}{l}-0.068 \\
(0.104)\end{array}$ & $\begin{array}{c}0.057 \\
(0.037)\end{array}$ \\
\hline Year fixed-effects & yes & yes & yes & yes & yes & yes \\
\hline Constant & $\begin{array}{c}0.306^{* * *} \\
(0.044)\end{array}$ & $\begin{array}{l}-0.006 \\
(0.198)\end{array}$ & $\begin{array}{c}0.174 \\
(0.199)\end{array}$ & $\begin{array}{c}0.149 \\
(0.201)\end{array}$ & $\begin{array}{c}0.308 \\
(0.381)\end{array}$ & $\begin{array}{c}0.185 \\
(0.174)\end{array}$ \\
\hline R-squared & 0.172 & 0.228 & 0.186 & 0.056 & 0.182 & 0.154 \\
\hline $\mathrm{N}$ & 37,514 & 1,315 & 1,585 & 1,840 & 463 & 2,750 \\
\hline
\end{tabular}

Notes: These are the coefficients of a linear probability model. The sample is restricted to students aged 17-20. The outcome variable is "high education track attendance". Reported standard errors are robust and clustered by household. * denotes statistical significance at the $10 \%$ level, $* *$ at the $5 \%$ level and $* * *$ at the $1 \%$ level. Source: German Microcensus (2005 and 2008) and GSOEP, author calculations. 